IZA DP No. 4957

Crossing the Border: Self-Selection, Earnings and Individual Migration Decisions

Simone Bertoli

Jesús Fernández-Huertas Moraga

Francesc Ortega

May 2010 


\title{
Crossing the Border: Self-Selection, Earnings and Individual Migration Decisions
}

\author{
Simone Bertoli \\ Institute for Employment Research \\ Jesús Fernández-Huertas Moraga \\ Institute for Economic Analysis, CSIC \\ and IZA \\ Francesc Ortega \\ Universitat Pompeu Fabra \\ and IZA
}

Discussion Paper No. 4957

May 2010

IZA

P.O. Box 7240

53072 Bonn

Germany

Phone: +49-228-3894-0

Fax: +49-228-3894-180

E-mail: iza@iza.org

Any opinions expressed here are those of the author(s) and not those of IZA. Research published in this series may include views on policy, but the institute itself takes no institutional policy positions.

The Institute for the Study of Labor (IZA) in Bonn is a local and virtual international research center and a place of communication between science, politics and business. IZA is an independent nonprofit organization supported by Deutsche Post Foundation. The center is associated with the University of Bonn and offers a stimulating research environment through its international network, workshops and conferences, data service, project support, research visits and doctoral program. IZA engages in (i) original and internationally competitive research in all fields of labor economics, (ii) development of policy concepts, and (iii) dissemination of research results and concepts to the interested public.

IZA Discussion Papers often represent preliminary work and are circulated to encourage discussion. Citation of such a paper should account for its provisional character. A revised version may be available directly from the author. 


\section{ABSTRACT \\ Crossing the Border: Self-Selection, Earnings and Individual Migration Decisions*}

Many empirical studies on the determinants of international migration flows rely exclusively on macro data, and do not account for migrants' self-selection. We analyze a very interesting episode in international migration for which we are able to gather individual-level data covering all relevant countries, namely the exodus of Ecuadorians to Spain and the US in the aftermath of the economic collapse of 1999. Specifically, we produce selection-corrected predictions of counterfactual individual earnings and use them to estimate a discrete-choice migration equation that allows for correlated errors across destinations and a rich structure of migration costs. We find that earnings significantly shape individual migration decisions, even in an episode in which Ecuadorians mostly chose Spain where earnings were lower than in the US, and they contribute to explaining the observed composition of migration flows. Moreover, our estimates show that changes in earnings at a particular destination have a larger effect on destination choice conditional on migration than on the scale of migration.

JEL Classification: F22, O15, J61, D33

Keywords: international migration, self-selection, earnings, individual-level data

Corresponding author:

Francesc Ortega

Department of Economics and Business

Universitat Pompeu Fabra

Ramon Trias Fargas, 25-27

Barcelona, 08005

Spain

E-mail: francesc.ortega@upf.edu

\footnotetext{
* The authors are grateful to Gordon Hanson, Giovanni Peri, Hillel Rapoport, participants at the World Bank-AFD Second International Conference on Migration and Development and at the Third INSIDE Workshop, at the EUI Microeconometrics Working Group and at a seminar at the University of Bari for their comments and suggestions. We would also like to thank Lídia Brun and Feray Koç for their helpful research assistance. This paper is part of the INSIDE research projects. Simone Bertoli received financial support from the RBNE03YT7Z project, funded by the Italian Ministry for Education, University and Research. Jesús Fernández-Huertas Moraga and Francesc Ortega received financial support from the ECO2008-04785 and 02779 projects respectively, funded by the Spanish Ministry for Science and Innovation, and they also acknowledge the support of the Barcelona GSE Research Network and of the Government of Catalonia. The usual disclaimers apply.
} 


\section{Introduction}

Why do people move across borders? And, in particular, what is the role of income differences in determining international migration flows? This is a simple yet challenging question, going back to Sjaastad (1962). Estimating the role of income in migration decisions requires predicting the earnings individuals can obtain at all alternative locations. But, of course, each individual is only observed in one single location.

A number of recent influential studies have made important contributions toward understanding the role of income in accounting for bilateral migration flows (Grogger and Hanson (2008), Belot and Hatton (2008), Ortega and Peri (2009), among several others). These studies typically use solely aggregate data, so that country-wide average income figures specifically, GDP per capita - are used to proxy potential migrants' earnings at destination. This choice - which is severely constrained by data availability - implicitly rests on two assumptions, namely that destination countries do not differ as far as the transferability of migrants' skill is concerned, and that there are no individual-specific unobserved factors that simultaneously influence earnings and the decision to migrate. Still, none of these two assumptions is fully consistent with the findings of the empirical literature on the assimilation of the immigrants (see Chiswick (1978) and Borjas (1985)), and the theoretical insights on migrants' self-selection (see Roy (1951), Sjaastad (1962) or Borjas (1987)).

On the other hand, the internal migration literature (e.g. Dahl (2002); Bayer, Keohane, and Timmins (2009); Kennan and Walker (2009)) employs individual-level data. It is a wellestablished fact in the internal migration literature that failing to account for unobserved ability or any other factor that affects simultaneously the migration decision and expected earnings can represent a critical source of bias.

Our contribution is the estimation of an international migration model using individuallevel earnings data coming from different countries and sources. The model allows for unobserved individual-specific factors influencing both earnings and migration decisions, as in the Roy-Borjas model. In the estimation of the earnings equation, we control for self-selection using state-of-the-art techniques (Dahl (2002)) from the internal migration literature. In the estimation of the migration decision, while controlling for a rich structure of migration costs, we relax the independence of irrelevant alternatives assumption, so that migration decisions do not respond to changes in earnings differentials but differentially to changes in earnings in the various locations. 
This approach is used to analyze a recent major migration episode, namely the wave of Ecuadorian migration which was triggered by the late 1990s economic crisis, when approximately 600,000 individuals left from a country with a population of 12.7 million over a few years (1999-2005). This migration episode also offers the chance to address a key challenge, the one represented by data requirements, as recent Ecuadorian migrants moved towards just two main destinations: the US and Spain. We merge information on Ecuadorians contained in three comparable household surveys collected in Ecuador, the National Survey on Employment and Unemployment in the Rural and Urban Areas 2005 (ENEMDU 2005), the US, the American Community Survey 2007 (ACS 2007), and Spain, the National Immigrant Survey 2007 (ENI 2007).

This particular international emigration episode is also interesting for another reason. Namely, the number of Ecuadorians that migrated to Spain over our period of interest was roughly three times larger than the corresponding flow to the US (Table 1). This is puzzling given the large difference in per capita incomes between the two destinations ${ }^{1}$ and the existence of pre-crisis Ecuadorian migration networks in the US but not in Spain (Jokisch and Pribilsky (2002)). Thus this episode poses a challenging test for any income-maximizing theory of migration.

Our main result is that earnings differences were relevant determinants of the decision to migrate, even in an episode where most migrants preferred a lower income destination (Spain) over a higher income one (the US). The estimates also show that changes in earnings at a particular destination have a larger effect on destination choice conditional on migration than on the scale of migration. In terms of our model, the reason for this pattern is that migrants tend to have above-average propensities to migrate. As a result their choices are more sensitive to changes in earnings at a particular destination than those of the average stayer, characterized by a low propensity to migrate.

Our econometric analysis confirms the empirical relevance of the argument that unobserved individual specific factors need to be adequately addressed in the choice of the estimation procedure. The application of the selection-control procedure proposed by Dahl (2002) demonstrates that the non-random selection in unobservables biases the counterfactual incomes that we would obtain from simple Mincerian regressions, and this would consequently

\footnotetext{
${ }^{1}$ The 2006 GDP per capita in PPP US Dollars was 44,000 in the US, 29,000 in Spain and 7,000 in Ecuador (World Bank (2008)).
} 
bias the estimation of the migration decision model. Reassuringly, in this particular case, the bias is not excessively large.

The time-equivalent implicit migration costs that we recover from the model imply that the cost of moving to the US is several times larger than the corresponding cost of going to Spain. This difference could be related to the cultural and linguistic proximity between Ecuador and Spain, and to the relatively more generous Spanish welfare state. We provide suggestive evidence showing that the effects of the progressive tightening of the US immigration policies, which began in the mid 1990s together with the relatively lax Spanish immigration policy towards Ecuadorians (at least until August 2003) also contributed to shape the pattern moving costs, and policy-induced migration costs (Beine, Docquier, and Özden (2009)) indeed constrained location choice. Networks, which did play a role in this migration episode (Bertoli (2010)), probably lowered the cost of moving to the US, but their effect is overshadowed by the influence of the other country-specific factors described above. The variability of migration costs across gender and educational groups is in line with the models put forward by Chiquiar and Hanson (2005) or McKenzie and Rapoport (2009).

This paper is related to several strands of research. It is most relevant in terms of the recent work on the determinants of international migration flows, such as Grogger and Hanson (2008), Belot and Hatton (2008), Ortega and Peri (2009), Mayda (2008), Pedersen, Pytlikova, and Smith (2006) and Clark, Hatton, and Williamson (2007). As noted earlier, all these studies rely on aggregate data. In our use of individual earnings data for different countries, our work is in the vein of Clemens, Montenegro, and Pritchett (2008) who report wages of comparable workers with the same nationalities across different destination countries, and Batista (2008) who controls for unobserved heterogeneity when estimating individual-level counterfactual wages. Neither of these two studies estimates a migration decision equation. Our paper is also related to other studies in the international migration literature that use micro data.Chiquiar and Hanson (2005), McKenzie and Rapoport (2009) or Fernández-Huertas Moraga (2009) study Mexico-US migration but are not concerned about the income-sensitivity of migration. Hanson and McIntosh (2008) also deal with Mexican emigration to the US and assess the factors behind long-run trends in the flows, establishing the relevance of labor supply shocks. Their work is extended to Latin American emigration in general in Hanson and McIntosh (2009). One of the channels through which labor supply shocks could be operating are wages in origin countries so this could be seen as 
one of the deep causes of our results.

Methodologically, our study is related to the research on the determinants of internal migration. Some influential contributions are Nakosteen and Zimmer (1980), Falaris (1987), Falaris (1988) and, more recently, Dahl (2002), Kennan and Walker (2009)) and Bayer, Keohane, and Timmins (2009). In their attention to self-selection, these studies are also related to the large literature on selection-correction methods (Heckman (1979), Lee (1983), Dubin and McFadden (1984), Dahl (2002), Bourguignon, Fournier, and Gurgand (2007), Bayer, Khan, and Timmins (2008), or Hamermesh and Donald (2008) among many others). Finally, this paper also contributes to the literature that analyzes the Ecuadorian migration episode and the crisis that generated it. Some relevant papers in this area are: Jokisch and Pribilsky (2002), Bertoli (2010), Gratton (2007), Jácome (2004) or Bertoli, FernándezHuertas Moraga, and Ortega (2010).

The rest of the paper is structured as follows. Section 2 introduces a simple migration decision model. Section 3 outlines an estimation approach that is consistent with our underlying theoretical model. Section 4 briefly sketches the salient features and the economic determinants of the Ecuadorian migration that followed the 1999 crisis. Section 5 describes the data sources that we draw upon to build our joint dataset, and it presents the relevant descriptive statistics. Then, Section 6 deals with the implementation of the estimation methodology, and Section 7 discusses the results from our individual-level estimation of the income responsiveness of international migration decisions and it analyzes the pattern of the implicit migration costs that can be recovered from the estimates of our model. Finally, Section 8 concludes. All figures and tables are collected at the end of the paper.

\section{The Model}

We consider the following version of the Roy (1951) migration model. All individuals start out in location $j=1$. Each individual chooses whether to migrate to one of either two potential destinations $(j=2,3)$. Observing all relevant variables, each individual compares the utility from migrating to each destination with the utility from staying in the location of origin, and then opts for the utility-maximizing alternative. From the point of view of the econometrician, individuals differ both in observable and unobservable characteristics. Crucially, part of the latter affects both the decision to migrate and the realization of earnings 
at destination. More formally, our empirical model has two inter-related equations: a discrete migration-choice equation (1) and a wage equation (2). That is, for each location $j=1,2,3$,

$$
\begin{aligned}
& U_{i j}=V_{i j}+v_{i j}^{m}=\alpha w_{i j}+x_{i}^{\prime} \beta_{j}+\left(\lambda_{j} \sigma_{i}+\varepsilon_{i j}^{m}\right) \\
& w_{i j}=z_{i}^{\prime} \gamma_{j}+v_{i j}^{w}=z_{i}^{\prime} \gamma_{j}+\left(\pi_{j} \sigma_{i}+\varepsilon_{i j}^{w}\right) .
\end{aligned}
$$

In equation (1), the dependent variable is the latent utility that individual $i$ attaches to location $j$. Utility includes a deterministic component $\left(V_{i j}\right)$, which depends on the log of labor earnings at that location $\left(w_{i j}\right)$ and on a vector of individual characteristics $\left(x_{i}\right)$, and an unobserved stochastic component $v_{i j}^{m}$. This is the sum of an individual-specific term $\left(\sigma_{i}\right)$ and an individual-location-specific shock $\left(\varepsilon_{i j}^{m}\right) . v_{i j}^{m}$ captures all the variables that are relevant to the decision-maker but are unknown to the econometrician. For instance, $\varepsilon_{i j}^{m}$ will be high for individuals that have relatives already living in destination $j{ }^{2}$ We assume that $\lambda_{1}=0$ whereas $\lambda_{j} \geq 0$ for $j=2,3$. Under these assumptions it is natural to interpret $\sigma_{i}$ as the unobserved individual propensity to migrate. ${ }^{3}$ Equation (2) specifies individual log wages in each location as a function of observable $\left(z_{i}\right)$ and unobservable characteristics $\left(\sigma_{i}\right.$ and $\left.\varepsilon_{i j}^{w}\right)$. Importantly, we allow for the propensity to migrate $\left(\sigma_{i}\right)$ to affect also wages. ${ }^{4}$ Following Grogger and Hanson (2008), we will also experiment with specifications featuring wages in levels in our empirical analysis of equation (1).

To complete the description of the model we turn to the stochastic specification. We assume that all random draws in $\left\{\varepsilon_{i 1}^{m}, \varepsilon_{i 2}^{m}, \varepsilon_{i 3}^{m}, \varepsilon_{i 1}^{w}, \varepsilon_{i 2}^{w}, \varepsilon_{i 3}^{w}, \sigma_{i}\right\}$ are independent across individuals. Moreover, random variables $\left\{\varepsilon_{i 1}^{m}, \varepsilon_{i 2}^{m}, \varepsilon_{i 3}^{m}\right\}$ and $\left\{\varepsilon_{i 1}^{w}, \varepsilon_{i 2}^{w}, \varepsilon_{i 3}^{w}\right\}$ are, respectively, independently distributed across alternatives with c.d.f. $F^{m}$ and $F^{w}$. The c.d.f. of propensity to migrate $\sigma_{i}$ is $F^{\sigma}$ with $E\left(\sigma_{i}\right)=0$ and $E\left(\sigma_{i} \varepsilon_{i j}^{m}\right)$ for $j=2,3$. We also assume that the covariate vectors $\left(x_{i}\right.$ and $\left.z_{i}\right)$ are uncorrelated with $\varepsilon_{i j}^{m}$ and $\varepsilon_{i j}^{w}$.

Individual unobserved heterogeneity in the propensity to migrate has two important implications. First, it generates a nested structure. Namely, it causes the unobservable component in the migration equation $\left(v_{i j}^{m}\right)$ to be correlated across destinations, for a given

\footnotetext{
${ }^{2}$ Alternatively, term $\varepsilon_{i j}^{m}$ can be interpreted as the level of fluency of the individual in the language spoken in destination $j$ or the degree of transferability of his human capital although the average degree of transferability of human capital can also be counted as a part of $\beta_{j}$.

${ }^{3}$ Note that if $\lambda_{j}>0$ for both destinations $(j=2,3)$, then there will be positive correlation between $v_{i 2}^{m}$ and $v_{i 3}^{m}$.

${ }^{4}$ We normalize $\pi_{1}=0$. Note that if $\pi_{j}$ and $\lambda_{j}$ are positive for both destinations then high- $\sigma_{i}$ individuals will be both more likely to migrate and to obtain above-average earnings at destination.
} 
individual. Meanwhile, under our assumptions, there is no correlation between the error term in location 1 and in locations 2 or 3. Specifically,

$$
\begin{aligned}
& E\left(v_{i 2}^{m} v_{i 3}^{m}\right)=\lambda_{2} \lambda_{3} E\left(\sigma_{i}^{2}\right) \\
& E\left(v_{i 1}^{m} v_{i j}^{m}\right)=0 \quad j=2,3
\end{aligned}
$$

Secondly, unobserved heterogeneity introduces a selection bias in the estimation of the wage equation. Namely, migrants are not a random sample of the original population. That is, they will tend to have systematically high or low wage draws. For example, suppose that $\sigma_{i}$ is a measure of risk aversion. Less risk averse individuals will be more likely to migrate. At the same time, they will be more likely to self-select into more risky jobs, which should offer a risk premium over the wage in non-risky jobs. This selection bias has important practical implications. Naturally, in our data we only observe labor earnings in one location for each individual. Thus, the estimation of the determinants of migration choices (equation (1)) requires generating counterfactual earnings for the other locations. This needs to be done in a way that accounts for self-selection into migration. In the context of international migration, this is the key innovation of the exercise we carry out in the following sections.

Let us briefly discuss the sources of identification in our approach. The wage regression is essentially a standard Mincer regression that accounts for self-selection into migration, where the coefficients are identified from individual variation in each location. Turning to the migration equation, the wage coefficient $(\alpha)$ is identified from individual variation both within and between locations. In contrast, in studies using only macro data, the identification is purely based on the correlation between the proportion of migrants and average per capita incomes across destinations. As a result, the estimate of the earnings coefficient may suffer from omitted variable bias. It is easy to think of omitted country characteristics, such as the quality of public services or natives' attitudes toward immigrants, that are correlated with income per capita and affect the attractiveness of a location. In contrast, equation (1) includes country-specific intercepts that account for all such factors.

Finally, it is well known that, in random utility models, not all the coefficients on the individual-specific characteristics in the migration equation are identified. We follow the convention of normalizing the coefficients of the original location to zero, that is, $\beta_{1}=0$. The coefficients on the variables that are not location-specific need to be interpreted as relative to their effect on the normalizing location (the origin country in this case). Thus, we interpret $x_{i}^{\prime} \beta_{j}$ (for $j=2,3$ ) as the net gain from migration to a particular destination. Obviously, 
$-x_{i}^{\prime} \beta_{j}$ can be interpreted as the net cost of migration to destination $j=2,3$. In our application these net costs of migration will vary at the individual level, reflecting differences in gender, age, education, marital status and household composition. Identification of the terms in the variance-covariance matrix of the migration equation depends on the stochastic specification of the model, which we discuss further in the next section.

\section{Estimation}

As noted already, unobserved heterogeneity in the propensity to migrate affecting also earnings has two important consequences for estimation: it creates a selection bias in the wage equation and it introduces correlation across the error terms of the location equation. Typically, due to data constraints, the versions of the Roy model that are estimated in the literature on international migration are special cases of the model above. In particular, researchers commonly assume that the unobserved terms in the latent utility equation $\left(v_{i j}^{m}\right)$ are independent across locations (Grogger and Hanson (2008)). In the context of our specific model, this amounts to assuming that $\sigma_{i}=0$ for all $i$. Note that under this (strong) assumption our model would not display a self-selection problem in the wage equation. Namely, it would be appropriate to assign to migrants a counterfactual wage had they not migrated equal to the average wage among non-migrants with the same observable characteristics. This approach is in stark contrast to the industry standard in the literature on internal migration, where several studies have argued forcefully against ignoring individual unobserved heterogeneity in propensities to migrate correlated with the wage generating process. The richer data available to study internal migration flows has led researchers to develop techniques to estimate versions of the Roy model where self-selection into migration is taken into account (Dahl (2002), Kennan and Walker (2009) or Bayer, Khan, and Timmins (2008), among others).

The key contribution of our paper is to identify an important international migration episode for which we are able to assemble high-quality individual-level data for migrants and non-migrants, covering all the relevant destinations. We are then able to apply the methods developed in the internal migration literature to estimate the model presented in the previous section.

As noted earlier, we need to tackle two main challenges. First, the error terms in the mi- 
gration equation may be correlated across alternatives. ${ }^{5}$ As a result, estimating a conditional logit model would not be appropriate. Instead the particular correlation structure in equations (3) and (4) nicely fits the structure of the nested logit model (MacFadden (1978)). ${ }^{6}$ There is yet a second challenge in the estimation of the model: our modeled unobserved heterogeneity $\left(\sigma_{i}\right.$ in particular) introduces a selection problem in the wage equation. The observed sample of individuals in a given destination may not be a random sample of the population of origin. Migrants will tend to have high migration propensities to that destination, which may systematically bias their wage draws. As a result, the estimated coefficient on the impact of income on migration $(\alpha)$ is likely to be biased. Moreover, we use data on actual earnings of migrants, which requires fewer imputation assumptions that are typically made in the international migration literature, where natives' income or GDP per capita are frequently used.

Our estimation of the system of equations (1) and (2) is done in two stages. First, we estimate individual, location-specific after-tax earnings correcting for self-selection using the method in Dahl (2002). We use these estimates to produce counterfactual earnings in each location for each individual. Second, we estimate the discrete location-choice equation (1). The observable part of the utility associated to each location is based on the earnings predictions computed in the first stage, as well as a number of individual controls. We make distributional assumptions that lead to a random-utility nested logit model. This model takes into account the discrete nature of the location choice in our environment (three locations) and it is able to accommodate the structure of correlations generated by our modeled unobserved heterogeneity in individual propensities to migrate. We bootstrap standard errors to account for the two-stage estimation procedure.

We next provide some further details on our estimation method. Let us start with the selfselection problem in the wage equation. We apply the correction proposed by Dahl (2002) with a small modification. First, we divide the population into mutually exclusive cells defined by observable characteristics: age, education, gender, marital status, and household

\footnotetext{
${ }^{5}$ This implies that independence of irrelevant alternatives (IIA) fails.

${ }^{6} \mathrm{~A}$ multinomial probit would be an alternative estimation method that is consistent with our model; in our three-location model the two methods are likely to deliver very similar results because of the similarity of their variance-covariance matrices. The nested logit has the advantage of closed-form expressions for the choice probabilities, which prove very useful in providing intuition for the magnitudes implied by the estimated coefficients
} 
size. Second, for each cell, we compute the proportion of individuals that chose to stay and work in the home country $(j=1)$ and the proportions that chose to migrate to each destination and work for a wage there $(j=2,3)$. Here is where we slightly depart from Dahl (2002). While he limits his study to working-male individuals and disregards the issue of selection into employment, we decide not to restrict our sample and consider selection into employment and selection into migration jointly, following the discussion in Hamermesh and Donald (2008). Thus, we estimate the following selection-corrected earnings equation:

$$
w_{i j}=z_{i}^{\prime} \gamma_{j}+f_{j}\left(p_{i j}\right)+\varepsilon_{i j}^{w}
$$

where the new term $f_{j}\left(p_{i j}\right)$ is a polynomial function of the probability that an individual $i$ chooses location $j$ and decides to work for a wage there, calculated as the proportion of individuals with observable characteristics in the same cell that chose to live and work in location $j$. Intuitively, this polynomial term corrects for the fact that employed migrants to a particular destination have a higher unobserved propensity to migrate and work, which may also influence their earnings realization. The assumption behind Dahl's method is that unobservable heterogeneity within cells is relatively small. ${ }^{7}$

Once we obtain selection-corrected individual wages, we turn to the second stage: the discrete choice migration problem. Our model can be estimated with a nested logit model once we assume that the individual-location-specific shock $\left(\varepsilon_{i j}^{m}\right)$ in equation (1) follows an Extreme Value Type-I distribution because this implies that the whole error term $\left(v_{i j}^{m}\right)$ follows a Generalized Extreme Value distribution. Specifically, we partition the three locations into two nests: a singleton containing only the home country (1) and a duple with the two potential destinations (2 and 3). The nested logit allows for positive correlation within nests but imposes zero correlation across nests, which is precisely the correlation structure of our model.

The parameters to be estimated are coefficients vectors $\alpha$ and $\beta$ together with the dissimilarity coefficient $\tau$, which controls the degree of correlation between the idiosyncratic

\footnotetext{
${ }^{7}$ Note that the correction term is indexed by $j$. Thus, here we are allowing for the degree of selection to vary by destination. The correction has been shown to be more efficient when including a higher order polynomial, containing also the proportions of individuals in the other locations. We follow this approach. Bourguignon, Fournier, and Gurgand (2007) compare Dahl's estimation procedure with others previously developed and widely used by the literature: Lee (1983) and Dubin and McFadden (1984). They conclude that Dahl's and their own variant of Dubin and McFadden (1984) are preferable to Lee's method.
} 
shocks of the two alternatives in the non-trivial nest, $\rho_{v_{i 2}^{m}, v_{i 3}^{m}}$. The exact relationship is:

$$
\tau=\sqrt{1-\rho_{v_{i 2}^{m}, v_{i 3}^{m}}}
$$

and the correlation coefficient can be related to the model parameters as follows:

$$
\rho_{v_{i 2}^{m}, v_{i 3}^{m}}=\lambda_{2} \lambda_{3} \frac{E\left(\sigma_{i}^{2}\right)}{\left[\lambda_{2}^{2} E\left(\sigma_{i}^{2}\right)+E\left(\left(\varepsilon_{i 2}^{m}\right)^{2}\right)\right]\left[\lambda_{3}^{2} E\left(\sigma_{i}^{2}\right)+E\left(\left(\varepsilon_{i 3}^{m}\right)^{2}\right)\right]}
$$

Coefficient $\tau$ is important for two reasons. First, when $\tau=1$, i.e. $\rho_{v_{i 2}^{m}, v_{i 3}^{m}}=0$, the model collapses to the standard conditional logit model. Second, the value of $\tau$ determines whether the estimated model is consistent with utility maximization or not ${ }^{8}$.

A great advantage of the nested logit model is that it delivers closed-form solutions for the choice probabilities. It is easy to show that

$$
\begin{aligned}
& p_{1}=\frac{e^{V_{1}}}{e^{V_{1}}+\left(e^{V_{2} / \tau}+e^{V_{3} / \tau}\right)^{\tau}} \\
& p_{j}=\frac{\left(e^{V_{2} / \tau}+e^{V_{3} / \tau}\right)^{\tau}}{e^{V_{1}}+\left(e^{V_{2} / \tau}+e^{V_{3} / \tau}\right)^{\tau}} \frac{e^{V_{j} / \tau}}{e^{V_{2} / \tau}+e^{V_{3} / \tau}} \quad j=2,3
\end{aligned}
$$

These expressions are quite intuitive. Equation (8) characterizes the probability of staying in the country of origin (location $j=1$ ). This expression is a function of the expected utility associated to staying in the country relative to the expected utility from migration, which is an aggregate of the expected utilities in each possible destination. We note that the latter aggregation is a function of the dissimilarity parameter $\tau$. When $\tau=1$, all locations are treated symmetrically. Regarding equation (9), the two terms on the righthand side correspond to the probability of migrating (to $j=2$ or 3 ) times the probability of choosing destination $j$, conditional on migration. Clearly, an increase in, say, $V_{2}$ increases the probability of choosing that destination both because it increases the migration rate and because it makes destination 2 more attractive relative to destination 3 .

\section{The Ecuadorian Crisis}

We now discuss the nature of the Ecuadorian exodus, which was mainly directed to the US and Spain. Ecuador was hit by a major economic and financial crisis at the end of

\footnotetext{
${ }^{8}$ Daly and Zachary (1979) and MacFadden (1978). Börsch-Supan (1990), Herriges and Kling (1996), Koning and Ridder (2003) and Ibáñez (2006), among others, establish different sets of conditions for the estimates of the parameters of a nested logit model to be consistent with utility maximization. In all of them, a dissimilarity parameter in the interval $(0,1]$ is a sufficient condition.
} 
the 1990s, induced by a remarkable series of adverse shocks. The price of oil, which still represents the single largest revenue item in the Balance of Payments and a crucial fiscal resource, reached a historical low in 1998. In the same year, the coastal provinces suffered from the floods induced by El Niño rains, which caused major infrastructure disruptions and severely hurt the agricultural sector, with a $\$ 2.6$ billion estimated damage, representing 13 percent of GDP (IMF (2000)). These factors compounded the macroeconomic instability existing in the country, and led to the collapse of the domestic currency, the sucre, and to a large-scale banking crisis. The Ecuadorian economic system was already de facto dollarized (Jácome (2004)), and the depreciation of the Sucre impaired the ability of the debtors to pay back the dollar denominated loans they had received, thus seriously deteriorating the balance sheets of domestic banks. Notwithstanding huge injections of liquidity on the side of the Ecuadorian Central Bank and the introduction of a public blanket guarantee of all deposits, the fears of a widespread banking crisis mounted, and the government decided to freeze bank accounts in March 1999, in a desperate attempt to prevent a bank run. By the end of the year, Ecuador was experiencing a 2-digit monthly rate of inflation, and its real GDP per capita had declined by 7.6 percent (see Figure 1).

The government decided to adopt the dollar as a legal tender of exchange in January 2000 to avoid the incipient risk of hyperinflation, and to try to revive credit operations at a time when 16 out of 36 domestic banks had already been closed or had gone under public stewardship (Jácome (2004)). Dollarization was implemented at a markedly undervalued conversion rate, as the decision to dollarize had not been agreed upon with international financial institutions, so that the Central Bank had to buy back the domestic monetary base with its limited holdings of foreign reserves. This induced a massive "once-and-forall price-level adjustment" (Beckerman and Cortés-Douglas (2002)), as the consumer price index rose by 96 percent in 2000, and it thus imposed a heavy toll on real wages. As Figure 1 shows, Ecuador experienced a moderately positive rate of growth in per capita GDP in 2000, which strengthened after 2001, when dollarization began to produce beneficial effects on price stability. Despite the incipient economic recovery, the crisis had produced some long lasting effects on Ecuadorian households. High inflation had substantially eroded the real value of their savings, and a large share of payments to depositors in failed banks were still pending almost ten years after the crisis (Laeven and Valencia (2008)), the government guarantees notwithstanding. 
The 1999 crisis triggered an unprecedented wave of international migration out of Ecuador, with approximately 600,000 individuals leaving over the 1999-2005 period (Ramírez Gallegos and Ramírez (2005); Bertoli, Fernández-Huertas Moraga, and Ortega (2010)), from a country with a total population of 12.7 million, according to the 2001 Population Census. Crucially for our analysis, Ecuadorian migrants flocked essentially to only two main destinations. Based on our estimates, the US and Spain absorbed 80 to 90 percent of the Ecuadorian migration induced by the crisis. ${ }^{9}$ Figures 2 and 3 report inflows of Ecuadorians into the US and Spain on an annual basis. Clearly, inflows surged between 1999 and 2003. Around 2004 flows into both countries were back to the respective pre-crisis levels. Interestingly, although the timing of migration flows is similar to both destinations, the size of the flows differs substantially. The Ecuadorian population in the US increased from 272,000 individuals before the crisis (2000 US Census) to 394,000 in 2005 (ACS 2007). In comparison, over the same

period Ecuadorian inflows to Spain were three times as large. Specifically, the Ecuadorian population in Spain grew from 76,000 (2001 Spain Census) to 457,000 individuals (2005 Local Population Registry). The sudden economic collapse and the resulting surge in Ecuadorian migration at the time of the economic crisis is an important feature for our analysis. It provides an unusually clean "push shock", and it also justifies treating education as exogenous with respect to the prospect to migrate at the time of the shock.

\section{Data}

\subsection{Data sources}

Our analysis requires individual-level data for the three countries over our period of interest. We describe below the three sources that we use to create our combined dataset. For Spain, we rely on the National Immigrant Survey (or ENI in the Spanish acronym), which was conducted in 2007 on a sample of 15,500 foreign-born residents in Spain. The survey covers both the legal and the undocumented foreign-born population and it is the first nationally representative immigrant survey conducted in Spain. The timing of the Spanish survey fits well with the need to focus on the Ecuadorian migrants who left over the 1999-2005 period, as it is well known that immigrant surveys have trouble to adequately account for very recent arrivals. For the US, we use the 2007 American Community Survey (ACS 2007). Its sample

\footnotetext{
${ }^{9}$ Estimates based on the 2001 Ecuador Census and the ENEMDU 2005.
} 
is approximately 2.5 percent of the resident population in the US. For Ecuador we choose the December 2005 round of the National Survey on Employment and Unemployment in the Rural and Urban Areas (or ENEMDU in the Spanish acronym). This is a nationally representative labor market survey that is conducted once a year.

We merge the three datasets, appropriately weighted. Our merged dataset contains information on age, gender, marital status, household size, education, years since migration, employment status, occupation, and labor earnings. Our sample is limited to all individuals who were born in Ecuador between 1949 and 1982, and (when they did so) left Ecuador between 1999 and 2005, our reference period. These individuals were between 16 and 49 years old and living in Ecuador in 1998, at the onset of the migration episode. This age restriction on the sample is common in the literature, as it covers the age group that is more likely to migrate for economic reasons. We opted for restricting by year of birth as opposed to age at the time of the survey to ensure that we compare migrants to stayers in the same birth cohort. Our final sample contains 28,122 stayers (ENEMDU 2005), 509 migrants to the US (ACS 2007), and 949 migrants to Spain (ENI 2005). ${ }^{10}$

\subsection{Descriptive statistics}

Tables 1 and 2 present some basic descriptive statistics on stayers and migrants to the two destinations. First, Table 1 provides estimates of the magnitude of the emigration flows by gender and educational status. Overall, the emigration flow represented approximately 6 percent of the total Ecuadorian population in our sample. Thus, the flow was very large in relative terms following the economic collapse and this can be considered as a huge international migration episode. Still, 94 percent of the population chose to remain in Ecuador. This suggests that migration costs are likely to have been very high in the aftermath of the crisis. Turning now to the destinations chosen by migrants, we note that the migration flow to Spain was three times larger than the migration flow to the US, with the proportion being higher among females and non-college graduates. As we next show, labor earnings for Ecuadorians in the US were much larger than in Spain or in Ecuador. The relatively small emigration to the US suggests that the costs to migrate to the US must have been very high,

\footnotetext{
${ }^{10}$ These figures amount to 70 percent of all Ecuadorians in the 2007 ACS and 77 percent in the 2007 ENI. We have also experimented restricting the sample to individuals ages 25-49 in 1998. The more restricted sample only has half of the observations.
} 
compared to Spain.

Table 2 shows that Ecuadorians in the US between 1999 and 2005 were predominantly male (54 percent), whereas Ecuadorians in Spain were gender balanced (49 percent female share). Among males, 14 percent of the Ecuadorians in the US had a college degree and their average age was 29 years at the time of migration. In comparison, only 8 percent of Ecuadorian males in Spain had a college degree. ${ }^{11}$ Interestingly, the share of college-educated among Ecuadorian women was higher than among men in both destinations (22 percent in the US and 15 percent in Spain), but still migrants to the US were more educated, on average, than migrants to Spain. In comparison, the share of college graduates among Ecuadorians that chose to stay in Ecuador was 14 percent for males and 13 percent for females. ${ }^{12}$

Table 2 also reports data on labor income, which are defined as pre-tax earnings over the 12 months prior to the survey (converted to 2005 US dollars). ${ }^{13}$ Clearly, earnings were the lowest in Ecuador and the highest in the US. For instance, Ecuadorian men earned, on average, $\$ 3,565$ in Ecuador, $\$ 15,979$ in Spain, and $\$ 26,896$ in the US. That is, migration to Spain and to the US is associated, respectively, to a 4-fold and a 7-fold increase in annual earnings in nominal terms. Naturally, the return to migration shrinks if we adjust for cost of living differences but it remains fairly large even then. ${ }^{14}$

Table 3 reports median annual earnings and employment rates by gender and destination. Let us examine first the data on employment rates. We note that employment rates for male college graduates were very similar in the three locations (92-93 percent) and slightly higher in Ecuador for male non-college graduates (95 compared to 90 percent). ${ }^{15}$ Instead, female employment rates for low-educated women were higher abroad than in Ecuador: 63 percent in the US and 81 percent in Spain, compared to 57 percent in Ecuador. For college-educated women, the employment rate was very similar in Ecuador and in Spain (over 80 percent)

\footnotetext{
${ }^{11}$ Individuals are regarded as college graduates if they have at least 4 years of college education.

${ }^{12}$ Bertoli, Fernández-Huertas Moraga, and Ortega (2010) analyze selection and sorting in the same dataset controlling for other observable characteristics. The basic message is the same one that results from the statistics shown in Table 2.

${ }^{13}$ Earnings in the ENEMDU 2005 are reported on a monthly basis, so we have annualized them for comparability with the other sources.

${ }^{14}$ Clemens, Montenegro, and Pritchett (2008) also find a 7-fold increase in nominal earnings for Ecuadorians in the US (7.3) with different sample selection criteria. When they add different controls, this ratio is reduced to around 4 or 5 .

${ }^{15}$ Recall that the Ecuadorian data is for 2005 , when the economic recovery was well under way in Ecuador.
} 
and lower in the US (63 percent). ${ }^{16}$ Employment rates were higher for males in all countries but the gap was small in Spain, thanks to very high female employment rates.

Turning to the earnings data, several features stand out. First, we note again the large migration premium for Ecuadorians that migrated to the US and to Spain. Second, the data reveal a large and fairly constant female penalty in earnings. Across the three locations, men earned over 40 percent more than women with comparable education levels. Third, the college premium differed greatly across the three locations. In Ecuador, the annual earnings of college-educated men were 2.6 times higher than the earnings of men with no college degree (the respective figure is 2.8 for women). Ecuadorian men in the US also displayed a handsome college premium of 42 percent (38 percent for women). Interestingly, the lowest college premium is found among Ecuadorians in Spain. Our data suggest that collegegraduate Ecuadorian men earned the same as non-college-graduates in Spain. Similarly, college-educated women earned only 4 percent more than Ecuadorian women without a college degree. These figures suggest that the education credentials of Ecuadorian migrants in Spain were often not recognized by Spanish employers. ${ }^{17}$

These differences in college premia are not driven by differences in length of stay in the new destination since our sample selection criteria ensure that migrants to the US and to Spain had been in the country roughly at the same time (6 years since migration, Table 2). Also, they are not the result of differences in legal status of immigrants across countries (see Bertoli, Fernández-Huertas Moraga, and Ortega (2010)). These figures, which reflect the earnings of migrants at destination as opposed to the average earnings of the total population in the destination country, are not in line with the pattern described by Grogger and Hanson (2008), who document that absolute differences in earnings between college and non-college individuals are increasing in the income level of a country, while relative differences are decreasing.

Overall, these descriptive statistics suggest three conclusions. First, the earnings of the

\footnotetext{
${ }^{16}$ The lower employment rates for female Ecuadorians in the US, relative to Spain, can be probably traced back to the larger share of tied movers among the women who migrated to the US. Jokisch and Pribilsky (2002), Sánchez (2004) and Bertoli (2010) document the importance of family reunification for Ecuadorian migrants in the US.

${ }^{17}$ It is well known that the college premium among Spanish-born individuals in Spain is lower than, for instance, among US-born individuals in the US. However, it is still positive and quantitatively important (González and Ortega (2008)).
} 
migrants were much higher than the earnings of the stayers, particularly for low-educated Ecuadorians. The ratios of median earnings of male migrants relative to stayers ranged between 6.7 (Spain) and 9.3 (US) for Ecuadorians without a college degree and from 2.6 (Spain) to 5.1 (US) for college graduates. Similar figures are obtained for women. Second, the earnings of migrants in the US were much higher than the earnings of migrants in Spain. Third, female employment rates in the US were much lower than female employment rates in Spain. Thus, there is a great degree of variability in the data across destinations and observable characteristics in terms of earnings and employment outcomes.

\section{Implementation}

The estimation of our model can be divided into two stages. The first stage requires producing individual-level estimates of earnings for each of the three locations that account for self-selection into migration. The second stage involves the estimation of a discrete choice migration model that allows for correlation across alternatives. Let us now provide some detail on the implementation of the estimation of our model.

\subsection{Selection-corrected individual earnings}

Construction of cells. We follow the methodology in Dahl (2002). ${ }^{18}$ We build different cell structures for Ecuador and for the two destination countries, to take into account the different sample size in the three locations. For Ecuador, we define 48 different cells, defined by gender, education (college versus non-college), age (three age groups), marital status (married versus non-married) and household size (larger or smaller than two individuals). The average cell size is 586 stayers with a maximum of 2,700 and a minimum of 9 . For the US and Spain, the more limited sample size reduces the number of cells to 8, defined by gender, education and household size. The average cell size is 178 migrants, ranging from a minimum of 32 to a maximum of $386 .{ }^{19}$ For each of these cells, the proportion of individuals who actually stays and works for a wage in Ecuador $\left(\hat{p}_{i 1}\right)$, migrates to the US and work

\footnotetext{
${ }^{18}$ As a robustness check, we replicate our estimation procedure using other standard corrections for selfselection. The results do not change much. All these methods are available in Stata's package SELMLOG, developed by Bourguignon, Fournier, and Gurgand (2007).

${ }^{19}$ Using the same cell division for migrants and stayers (either the coarser with 8 cells or the finer with 48 cells) does not affect our main results.
} 
for a wage there $\left(\hat{p}_{i 2}\right)$ or migrates to Spain and works for a wage there $\left(\hat{p}_{i 3}\right)$ will be used in the next step as the predicted probability that an individual belonging to a particular cell chooses to work in the respective location.

Identification would benefit from information affecting the propensity to migrate and work without affecting wages. We follow the literature on selection into employment and wages (Heckman (1979)) by using household size as a variable which can arguably affect selection into employment and migration without affecting wages directly ${ }^{20}$. In addition, we would have liked to separate the two sources of selection: migration and employment, as done by Hamermesh and Donald (2008), but we lack any credible information that should appear in the selection into employment equation and not in the selection into migration equation or viceversa. The use of the household size variable in the migration equation can be seen as controversial, since households are likely to be measured differently in each of our data sources. $^{21}$ To address this concern, we have re-estimated the whole procedure without using the household size variable at all and found that results did not change significantly. ${ }^{22}$

Estimation of the earnings equation. We estimate the following equation for log earnings:

$$
w_{i j}=z_{i}^{\prime} \gamma_{j}+f_{j}\left(\hat{p}_{i j}, \hat{p}_{i j^{\prime}}\right)+\varepsilon_{i j}^{w}
$$

where $z_{i}$ includes a constant, a college-graduate dummy, a female dummy, age and its square, a marital status dummy and nine occupational dummies ${ }^{23}$. Function $f_{j}\left(\hat{p}_{i j}, \hat{p}_{i j^{\prime}}\right)$ is Dahl's correction polynomial. The exact form is a second order polynomial in the retention probability for stayers and a second order polynomial in the retention and first-best probability for migrants plus an interaction term. The inclusion of occupational dummies in $z_{i}$ allows us to identify the earnings coefficient in the ensuing migration choice model without fully relying on non-linear functional forms. In addition, it allows us to control for a complex structure of migration costs (or net migration benefits) correlated with our observables, such

\footnotetext{
${ }^{20}$ We checked that our results below are robust to the inclusion of the household size variable on our wage equation directly. In that case, identification comes only from functional form.

${ }^{21}$ Bertoli (2010), following McKenzie and Rapoport (2009), provides evidence of a large incidence of whole household migration to both the US and Spain.

${ }^{22}$ Results are available from the authors upon request.

${ }^{23} \mathrm{We}$ use the 1-digit ISCO categories. US occupations are recoded from US OCC 2000 into ISCO-88 categories following Elliott and Gerova (2005).
} 
as networks, employment probabilities, migration policies in both countries, welfare state, etc. (see the discussion below). ${ }^{24}$

The standard errors for equation (10) need to take into account the fact that cell probabilities are also estimated with some error in the first step. To this end, we produce bootstrapped standard errors by running replications of the procedure in each of which we randomly select observations by country of choice up to the sample size with replacement.

Prediction of individual earnings for all locations. Next, we predict earnings in all three locations for all individuals in the sample, using the estimated equation (10). ${ }^{25} 26$

\subsection{The migration choice}

Using the predicted earnings from (10), we estimate a discrete choice migration model that allows for correlation across alternatives. We can summarize it by:

$$
U_{i j}=V_{i j}+v_{i j}^{m}
$$

for locations $j=1,2,3$. The first term of the right-hand side is the deterministic part of utility while the second is an idiosyncratic stochastic component defined in equation (1). Specifically,

$$
V_{i j}=\alpha \hat{w}_{i j}+x_{i}^{\prime} \beta_{j}
$$

The main explanatory variable for the probability of choosing a particular location is our estimate of expected log earnings at that location $\left(\hat{w}_{i j}\right)$. This estimate takes into account that migrants may not be a random sample of the original population, allowing for the degree of self-selection to vary by destination. In addition, the vector of individual earnings estimates takes into account that upon migration some individuals may be further self-selected into employment. We include controls for all the variables that were used in the previous steps:

\footnotetext{
${ }^{24}$ Our results can be replicated without significant changes without including occupational dummies.

${ }^{25}$ We assign the elementary occupation to non-working individuals; the results are not sensitive to different assignments.

${ }^{26}$ We also experiment with an alternative strategy to predict individual earnings. Namely, one can use actual earnings for the location that has been observed for each individual and then use predictions for the two counterfactual locations only. This barely affects our main estimates. The results from all of these auxiliary regressions are available from the authors upon request.
} 
gender, education, age, marital status and household size $\left(x_{i}\right)$. The stochastic specification of our model implies that $v_{i j}^{m}$ has a generalized extreme value distribution, which gives rise to the nested logit model. More specifically, we define two nests. The first nest is a singleton, containing only location 1 (Ecuador). The second nest contains locations 2 and 3 (the US and Spain).

\section{Results}

We estimate a two-equation Roy model for migration and earnings, which allows for unobserved heterogeneity in individual propensities to migrate that also affects earnings. Our estimation takes place in two steps, and we compute bootstrapped standard errors to account for the sequential nature of the estimation.

\subsection{Counterfactual earnings}

Recall the three main features of our earnings data. First, we use information on annual earnings of Ecuadorians in each location. Thus we do not need to rely on extrapolation based on earnings data for the native population. Second, we compute counterfactual aftertax earnings, by using the income tax schedule in each destination during our period of analysis. There are important differences in income tax rates between the three countries. As illustrated by Figure 4, income taxes are highest in Spain and lowest in Ecuador. ${ }^{27}$ Third, we are able to include a rich set of individual characteristics, usually not available in studies that use aggregate data. It is still possible that, even controlling for individual differences in observable characteristics, unobserved heterogeneity may bias our predictions for counterfactual earnings. To address this concern, we produce selection-corrected earnings, which is feasible thanks to our detailed individual-level information.

Let us now turn to the specification of our earnings equation. We estimate one equation for each of the three locations, on the sample of employed Ecuadorians who report positive

\footnotetext{
${ }^{27}$ For instance, consider an individual earning $\$ 20,000$. While she would be subject to a marginal tax rate below 10 percent in Ecuador and in the US the marginal tax rate in Spain would be almost 20 percent. The difference in taxation between the US and Spain implies that the gap in after-tax earnings is even larger than the gap in pre-tax earnings between the two destinations.
} 
earnings. $^{28}$ The dependent variable is the log of after-tax annual earnings (in 2005 US dollars) for Ecuadorians in each respective location. The right-hand side includes a vector of occupational dummies, a polynomial in age, and dummies for being female, having a college degree and being married. Including occupational dummies allows for a relatively high goodness of fit, which is important in order to produce rich predictions for counterfactual earnings. For each country, we estimate two models. The first model (labeled Mincer) does not control for self-selection, and amounts to a Mincer regression augmented with occupational dummies. The second model (labeled Dahl) corrects for self-selection into migration and employment à la Dahl (2002), that is, by including a polynomial with the cell probabilities defined in the implementation section above.

The results are reported in Table 4. Let us start with the Mincer model estimates (odd data columns). Two observations are worth noting. First, our estimates imply a large college wage premium in Ecuador (35 percent), compared to the US (around 8 percent) and Spain (0 percent). We note that the estimates for the US and Spain have high standard errors, reflecting the limited number of observations and the fact that we are including a vector of occupation dummies, which accounts for most of the variation in earnings. Second, we also find a very large female wage penalty in the three countries, although larger in Ecuador (35 percent) than in the US (26 percent) and Spain (27 percent).

We now turn to the Dahl earnings regression models, which correct for self-selection into employment and migration. The results are reported in the even data columns of Table 4. The main observation is that the estimates are very similar to the ones obtained in the Mincer models. That is, correcting for self-selection does not seem to make a large quantitative difference in the predictions for after-tax earnings, suggesting that our rich set of observable characteristics captures most of the relevant heterogeneity. There are, however, reasons to prefer the earnings predictions that correct for self-selection. As the last row in Table 4 shows, we reject the null of joint zero values of the correction Dahl parameters for the case of Ecuador (though not for the US and Spain). Thus the next step in the estimation uses the earnings predictions that correct for selection into employment and migration. As a robustness check, we also report our main results using earnings predictions based on the Mincer models.

\footnotetext{
${ }^{28}$ We trim 2.5 percent of the observations with the highest and lowest earnings although this does not significantly affect the results.
} 


\subsection{Location choice}

We now turn to the second stage of our estimation procedure, the discrete location-choice model based on our predicted counterfactual after-tax earnings. In practice it boils down to estimating a nested logit discrete-choice model and adjusting standard errors to account for the sequential nature of our estimation procedure.

The deterministic part of the utility associated to each location is assumed to be a function of (log) after-tax earnings, a country-specific intercept, and a list of individual controls, including age, age squared, gender, education, marital status and household size. Let us now briefly justify the choice of the variables, besides earnings. The country-specific intercepts account for differences in policies, institutions, culture, and cost of living across the three destinations. The vector of individual controls is meant to capture individual differences in the cost of migration. For instance, it is well known that women and individuals who are older, less educated, and have family ties are less likely to migrate. In particular, we note that the coefficient associated to the education variable captures only the effect operating through the cost of migration, since we are already controlling for earnings. Following the usual convention, we normalize to zero the intercept and the coefficients of all variables that do not vary across destinations for the Ecuador alternative.

Table 5 presents our estimates for a number of specifications. Column 1 presents our main results. The main explanatory variable is the log of annual after-tax earnings, which are counterfactual predictions based on the selection-corrected earnings equation (Dahl model in Table 4). First, let us focus on the main coefficient of interest. The earnings coefficient is positive and highly significant (0.623), indicating that higher expected earnings at a particular country increase the probability to locate there. We also note that the bootstrapped standard errors are relatively small $\left(0.263^{29}\right)$. Next, let us examine the robustness of this estimate across the remaining specifications. Column 2 presents the results when we use the $\log$ of pre-tax earnings, which delivers a very similar coefficient ${ }^{30}$. Column 3 presents the results when we use earnings predictions that do not correct for self-selection (Mincer's model in Table 4). The estimated coefficient is again very similar to the one found in column 1. In column 4 we assume that after-tax earnings enter linearly in the utility associated to

\footnotetext{
${ }^{29}$ The unadjusted (no bootstrap) standard error is 0.121 .

${ }^{30}$ Standard errors are much lower than in column 1 because - for all other model specifications - we are not reporting bootstrapped standard errors. Of course, that would be more appropriate but the computation time is not trivial.
} 
each location. Again, the estimated coefficient is positive and highly significant. Finally, we consider a model that assumes no correlation across alternatives in unobservables (conditional logit). As shown in column 5, the point estimate associated to after-tax earnings is again positive and significant, and approximately 20 percent larger than in column 1 (0.752), although the difference is not statistically significant. Taken together, these estimates suggest that earnings at destination are a robust determinant of migration choices. We discuss the magnitude of the effects and the coefficients associated to the individual controls below.

A second important observation is that the model with log after-tax earnings (column 1) appears to be a better specification than the model where earnings enter linearly (column 4). In particular, the estimated dissimilarity coefficient associated to specification 1 is $0.253^{31}$, which implies a within-nest correlation of 0.94. In contrast, specification 4 features a poorly estimated dissimilarity coefficient equal to 59.78, which is inconsistent with random utility maximization.

We now turn to the estimated coefficients of the individual controls. First, we note that the coefficient of the college-graduate dummy is positive but not significant in our main specification (column 1). Only in column 5 we find a positive and marginally significant value. That is to say, conditional on expected earnings in each destination, education plays at most a limited role in shaping international migration decisions. Second, being female is associated to a lower probability to migrate, especially to the US. The estimated coefficients are significant and tend to be larger in absolute value than the estimated coefficient for having a college degree. We comment on the estimates of the remaining individual controls later on, when we provide estimates of the implicit cost of migration.

The low overall level of statistical significance of the college and female dummies in Table 5 suggest that most of the rich observed patterns of selection and sorting in education in Ecuadorian migration flows must be generated by variation in expected earnings.

\subsection{The marginal effects of changes in earnings}

We next report on the magnitude of the effects of changes in earnings on location choice implied by our parameter estimates. It is helpful to start by exploiting the tractability of the nested logit model, which provides closed-form solutions for the choice probabilities

\footnotetext{
${ }^{31}$ We note that 76 percent of the estimates of this parameter in our bootstrapped replications fall below
} 1. 
(equations (8) and (9)).

We find particularly helpful to focus on the elasticity of the choice probabilities to changes in earnings at a particular destination. We shall denote this elasticity by $\epsilon_{j k}$, defined as:

$$
\epsilon_{j k}=\frac{\partial \ln p_{k}}{\partial w_{j}} \quad j, k=1,2,3
$$

The matrix below collects the whole matrix of elasticities, where element $(j, k)$ in the matrix corresponds to the percentage change in choice probability $p_{k}$ associated to a one percent increase in earnings in location $j$, for $j, k=1,2,3$. Namely, the matrix collecting all elasticities $\epsilon_{j k}$ is:

$$
\Sigma^{N L}=\alpha\left(\begin{array}{ccc}
1-p_{1} & -p_{1} & -p_{1} \\
-p_{2} & \frac{1}{\tau}\left[1-\left(1-\tau p_{1}\right) \frac{p_{2}}{p_{2}+p_{3}}\right] & -\frac{1}{\tau}\left[1-\left(1-\tau p_{1}\right) \frac{p_{2}}{p_{2}+p_{3}}\right] \\
-p_{3} & -\frac{1}{\tau}\left[1-\left(1-\tau p_{1}\right) \frac{p_{3}}{p_{2}+p_{3}}\right] & \frac{1}{\tau}\left[1-\left(1-\tau p_{1}\right) \frac{p_{3}}{p_{2}+p_{3}}\right]
\end{array}\right)
$$

which is a function of the dissimilarity parameter $\tau$. It is important to note that all elements of the matrix are pre-multiplied by $\alpha$, the coefficient on log earnings in the latent utility equation. Setting the dissimilarity parameter $\tau=1$ delivers the elasticity matrix for the simpler logit model, which we report further down.

Using our main set of estimates, we compute one matrix of elasticities for each individual, taking into account his or her individual controls, and then average over the whole sample. The resulting elasticities are

$$
\hat{\Sigma}^{N L}=\left(\begin{array}{rrr}
0.04 & -0.59 & -0.59 \\
-0.01 & 2.01 & -0.45 \\
-0.03 & -1.43 & 1.03
\end{array}\right) .
$$

Several points are worth noting. First, elasticities on the main diagonal are all positive while off-diagonal elements are all negative, as expected since the former are own-elasticities and the latter are cross-elasticities. Second, the own elasticity for Ecuador $\left(\epsilon_{11}\right)$ is much smaller than the own elasticities for the US and Spain (respectively, $\epsilon_{22}$ and $\epsilon_{33}$ ). Namely, a 10 percent increase in Ecuadorian earnings leads to an increase in the probability of staying in Ecuador equal to 0.4 percent whereas the same percentage increase in expected earnings in the US is associated to a 20.1 percent increase in the probability of migrating to the US. This large asymmetry simply captures the fact that most Ecuadorians stayed in Ecuador. Second, 
the elasticity associated to the probability of migrating to the US or Spain in response to a change in Ecuadorian earnings equals -0.59 for both destinations. We note that $\epsilon_{12}$ and $\epsilon_{13}$ are between-nest cross-elasticities. Third, the within-nest cross-elasticities are also high. In particular, the elasticity of a change in Spain's earnings on the probability of migrating to the US $\left(\epsilon_{32}\right)$ equals -1.43 , compared to -0.45 for the change in the probability of migrating to Spain in response to changes in US earnings $\left(\epsilon_{23}\right)$.

It is interesting to compare these elasticities to the ones that we would have obtained from the estimation of the more restricted conditional logit model. That is, if we had maintained unchanged the first stage of our estimation (the prediction of counterfactual earnings) but modified the second stage by imposing uncorrelated error terms across locations. This choice is logically inconsistent in our framework since it recognizes the potential existence of unobserved heterogeneity in propensities to migrate in the first stage but ignores it in the second. Still, we report below the corresponding matrix, based on the estimates of model 5 in Table 5:

$$
\hat{\Sigma}^{L}=\hat{\alpha}\left(\begin{array}{ccc}
1-\hat{p_{1}} & -\hat{p_{1}} & -\hat{p_{1}} \\
-\hat{p_{2}} & 1-\hat{p_{2}} & -\hat{p_{2}} \\
-\hat{p_{3}} & -\hat{p_{3}} & 1-\hat{p_{3}}
\end{array}\right)=\left(\begin{array}{rrr}
0.05 & -0.71 & -0.71 \\
-0.01 & 0.74 & -0.01 \\
-0.03 & -0.03 & 0.72
\end{array}\right)
$$

Inspection of the analytic expressions for the elasticities in matrices (14) and (16) reveals that the first row and the first column of the matrices are identical in the conditional and nested logit models ${ }^{32}$. As a result, between-nest cross-elasticities are very similar in the two cases. In contrast, the within-nest cross-elasticities are much smaller when unobserved heterogeneity in propensities to migrate is ignored (conditional logit). For example, an increase in expected earnings in Spain equal to one percent leads to a percentage change in the probability of migrating to the US equal to -0.03 percent according to the conditional logit estimates, compared to a -1.43 percent in the nested logit. This large discrepancy in the magnitude of the within-nest cross-effects between the two models is quite intuitive. As noted earlier, the correlation coefficient between the error terms in the nest containing the US and Spain is quite high (0.94), providing evidence that heterogeneity in propensities to migrate plays a large role. Among the subset of migrants the mean unobserved propensity to migrate is above average. As a result, these individuals (the migrant type, so to speak) are very sensitive to earning differences across the two potential destinations. As we discuss

\footnotetext{
${ }^{32}$ There is a difference in the estimate of $\alpha$, which happens to be very small empirically in this case.
} 
in detail below, an increase in expected earnings in one of these destinations, relative to the other, has a larger influence in their destination choice than what results from the conditional logit model.

This finding has important implications for the estimation of the effects of income in determining international migration flows. In studies using aggregate data it is often assumed that bilateral migration flows from one country to another are a function of the difference in expected earnings between those two countries, as implied by the conditional logit model. However, in the presence of individual heterogeneity in propensities to migrate bilateral migration flows are a nonlinear function of expected earnings (utilities) in all potential locations. To see this we use equations (8) and (9) to derive the log ratio of the probability to migrate to destination $j=2,3$ relative to the probability of staying in the country of origin $j=1$ :

$$
\ln \frac{p_{j}}{p_{1}}=\left(\frac{V_{j}}{\tau}-V_{1}\right)+(\tau-1) \ln \left(e^{V_{2} / \tau}+e^{V_{3} / \tau}\right)
$$

In the absence of unobserved individual heterogeneity in propensities to migrate, the error terms in the location choice equations are uncorrelated, implying a dissimilarity parameter $\tau=1$ (conditional logit). Only in this case the log odds ratio in the previous equation simplifies to

$$
\ln \frac{p_{j}}{p_{1}}=V_{j}-V_{1}=x^{\prime} \beta_{j}+\alpha\left(w_{j}-w_{1}\right)
$$

Our estimated dissimilarity coefficient is substantially below one $(\hat{\tau}=0.25)$, implying a correlation coefficient of 0.94 between the error terms in the US and Spain location equations. Consequently, the predictions of our estimated model differ substantially from those obtained by assuming away unobserved individual differences in the propensity to migrate. Consider, for instance, the implications of a simultaneous 1 percent increase in expected earnings in Ecuador and in the US on relative migration flows from Ecuador to the US. By definition of our elasticities,

$$
\frac{\partial \ln \frac{p_{2}}{p_{1}}}{\partial w_{1}}+\frac{\partial \ln \frac{p_{2}}{p_{1}}}{\partial w_{2}}=\epsilon_{12}-\epsilon_{11}+\epsilon_{22}-\epsilon_{21}
$$

This expression is exactly zero in the logit model, as can be checked easily using the expressions in equation (16). That is, in a model that ignores unobserved heterogeneity in propensities to migrate these changes in earnings would not trigger any migration flows from Ecuador to the US. But this is not the case here. Substituting the values for the elasticities 
from matrix (15), we obtain that the logs ratio increases by 1.39 percent. $^{33}$ In other words, a seemingly neutral change in relative earnings leads to an increase in the relative migration flow to the US. The intuition is that the increase in US expected earnings triggers a shift in the destination choice of individuals with a high propensity to migrate, who now choose to migrate to the US rather than to Spain.

It is interesting to compare our marginal effects of earnings to those obtained using only aggregate data, as in Grogger and Hanson (2008) or Ortega and Peri (2009). The former estimate a conditional logit, whereas the latter estimate a nested logit model with the same nested structure as here. Both studies use cross-country data. There are three main conceptual differences between our analysis and theirs. First, we use data on actual earnings of immigrants, rather than imputing them from GDP per capita in the destination country. Second, our counterfactual expected earnings account for the fact that migrants are likely to be self-selected. Finally, our discrete choice model allows for correlated errors across destinations. The estimated coefficient for log earnings (proxied by log income per capita) ranges between 3 and 5 (with standard error around one) in Grogger and Hanson (2008) and between 0.75 and 0.77 (with standard error around 0.25) in Ortega and Peri (2009). ${ }^{34}$ Our estimates of the coefficient on log earnings, around 0.6, are lower than in these two studies although not statistically different from those in Ortega and Peri (2009). An important difference with the latter study is that lacking individual-level data, Ortega and Peri (2009) cannot identify the dissimilarity parameter, which plays a crucial role in the computation of the cross-elasticities.

\subsection{Implicit costs of migration}

As emphasized in Hanson (2008), the largest gap in the literature on international migration is the limited understanding of the nature of migration costs. Clearly, these costs go well beyond the direct costs associated with physically moving from one location to another. Relevant indirect costs include the psychological costs related to being far away from family and friends, but also the costs of overcoming barriers to migration. For legal migrants, this may be the months or years waiting for a visa. For illegal migrants, these indirect costs may

\footnotetext{
${ }^{33}$ The reader can check that a simultaneous one percent increase in expected earnings in Ecuador and Spain leads to an increase of 0.43 percent in the log odds of migrating to Spain relative to staying in Ecuador.

${ }^{34}$ The coefficients are comparable since their models are nested in ours.
} 
include the consequences of being apprehended while attempting to cross the border or the probability of being discovered once in the destination country and then deported. ${ }^{35}$

Understanding what the main dimensions behind migration costs are is key to the analysis of our specific migration episode. After all, most Ecuadorians stayed in Ecuador and, among those that migrated, the majority chose to move to Spain even though the US offered substantially higher earnings opportunities. This implies that overall migration costs are very high, compared to earnings differences. Additionally, the perceived cost of migrating to the US must have been substantially higher than the cost of migrating to Spain.

The goal of this section is to provide estimates of the implicit cost of migration associated to each of the two destinations. We use our estimated model to produce average estimates of migration costs by gender and education level. Following the convention in the literature (Chiquiar and Hanson (2005) or McKenzie and Rapoport (2009), we express these implicit migration costs in time-equivalent units, as a fraction of Ecuadorian expected earnings.

Suppose, first, that our migration choice model only included earnings and a countryspecific constant in the right-hand side. In this case, it is straightforward to back out a measure of the implicit migration cost to each destination. The intercept for, say, Spain is a measure of the attractiveness of Spain relative to the baseline normalization (Ecuador). On the basis of equation (1), the units for this variable are "utils". The coefficient on expected earnings provides a scaled measure of the marginal utility of income. Thus, its inverse can be used to map "utils" into US dollars. Finally, multiplying the implicit attractiveness measure of each location by minus one we obtain our measure of alternative-specific implicit migration costs measured in US dollars. We note that, due to our normalization, the implicit migration cost associated to staying in Ecuador is zero.

Our model is richer than the stylized model described in the previous paragraph. In particular, it contains several individual characteristics, such as education, gender, age, and household size. However, the procedure above can be applied to provide measures of implicit migration costs which, in this case, will vary at the individual level. Table 6 presents our main results. The first column reports our estimate of average migration costs to the US relative to Ecuadorian earnings, disaggregated by gender and education. The second column presents analogous figures for Spain. Column 3 is the ratio of the previous two columns.

\footnotetext{
${ }^{35}$ Using cross-country panel data, Ortega and Peri (2009) empirically show that adopting more restrictive immigration policies leads to substantially lower actual immigration flows. In our model such a policy shift would imply higher overall migration costs.
} 
Bootstrapped standard errors are reported in brackets.

Three features of the table are worth noting. First, net migration costs are higher to the US than to Spain for all four groups. We find that the net cost of migrating to the US for males without a college degree is 8.5 times their Ecuadorian income (9.5 for females). Second, as expected, the estimated net migration costs are substantially higher for the US than for Spain: around 30 percent higher for non-college graduates and about twice as high for college graduates, for both genders. We note that female non-college graduates face the highest relative costs to the two destinations.

We must point out that net migration costs are clearly negatively related to education in both countries, as hypothesized by Chiquiar and Hanson (2005) and McKenzie and Rapoport (2009) among others. The literature on the determinants of international migration offers a menu of elements that our estimation method is containing in our so-called net migration costs in Table 6: immigration policy differences (Ortega and Peri (2009)), the role of networks (Beine, Docquier, and Özden (2009) or McKenzie and Rapoport (2009)), differences in access and generosity in the welfare state (Mayda (2008)), unemployment rates (Clark, Hatton, and Williamson (2007)), and so on. Our model controls for all of these factors as long as they are related to the observables in our location choice model but it is silent about which of them played the main role. Essentially, all these factors are buried in the country-specific intercepts and coefficients on observables.

Having shown that expected earnings matter for migration decisions (Table 5), some elements in our net migration costs are required to understand why most migrants preferred the Spanish destination over the US one, despite the much higher expected earnings in the US. In what follows, we provide an interpretation for what may have been the most likely determinants of implicit migration costs in our particular migration episode. Our discussion is based on a comparison of the average implicit migration costs across education and gender groups from Table 6. In particular, we discuss the roles of differences in the spread of earlier ethnic networks, in employment rates, in access to the welfare state and in immigration policy.

\subsubsection{Migrant networks}

As explained earlier, Ecuadorian migration to Spain started at the end of the 1990s (Figure 3). In contrast, Ecuadorians had been migrating to the US for several decades. Most of 
the Ecuadorians that had settled in the US came from two poor regions: Cañar and Azuay (see, for example, Jokisch and Pribilsky (2002) or Bertoli (2010)). Bertoli (2010), using only Ecuadorian data, shows the relevance of these networks in explaining migration patterns to the US. Since such long-standing networks were non-existent in Spain, it could be argued that networks are a factor that should have favored migration to the US over migration to Spain which, in our estimates, would be reflected in lower implicit migration costs for Ecuadorian emigrants to the US. Since flows were actually much higher to Spain than to the US, networks actually deepen the puzzle that most migrants chose Spain over the US.

\subsubsection{Employment rates}

As shown in Table 3, employment rates for males were very similar in the two destinations at all education levels. However, female employment rates were much higher for Ecuadorian immigrants in Spain than in the US: around 20 percentage points higher. This would tend to make Spain a more attractive destination for Ecuadorian emigrants than the US. In our estimation exercise, this attractiveness is reflected as smaller implicit net migration costs in Table 6. Thus, differences in employment rates may have been a relevant factor explaining emigration to Spain for Ecuadorian females but cannot account for the larger flow of Ecuadorian males to Spain (Table 1).

\subsubsection{Welfare state}

Another dimension that makes Spain a much more attractive destination for migrants, particularly if undocumented, than the US is the easy access to public services. In Spain all residents, regardless of their country of birth or their immigration status, have access to universal health care and public education. The only requirement is to be registered in the Local Population Registry. Registration does not require proof of legal status. In addition, Ecuadorians can benefit from a 1960 bilateral agreement between Ecuador and Spain regarding the contributions to the Social Security system. In short, the contributions to Spain's social security system by Ecuadorians are perfectly portable. ${ }^{36}$

\footnotetext{
${ }^{36}$ In particular, Article 4 of the bilateral agreement states that 'When an insured person has worked in the two countries without completing in either the minimum period of contribution necessary to receive the invalidity benefit and old-age pension provided for under the social security legislation of each country, the periods of contribution in each country shall be aggregated for the purpose of determining entitlement. The
} 
The greater generosity and the unrestricted access to Spanish welfare state provisions are likely to have been relevant factors driving down the implicit migration costs of moving to Spain rather than to the US. The same holds true for other country specific factors, such as the lower costs of living in Spain, and the cultural and linguistic proximity between Ecuador and Spain. In our estimation, this is captured by our Spain-specific intercept.

\subsubsection{Immigration Policy and risk of apprehension}

Bertoli, Fernández-Huertas Moraga, and Ortega (2010) have suggested that differences in immigration policy may have played a role. In the years between 1999 and 2005, the US was practically closed to Ecuadorians that wanted to migrate legally unless they could do so via family reunification. Moreover, Figure 2 suggests that a large fraction of Ecuadorian migrants to the US during this period may have been forced to migrate illegally, involving a higher monetary cost and a high risk of apprehension. ${ }^{37}$ Clearly, taking this risk into account may have reduced the utility associated to migrating to the US. In contrast, Ecuadorians that wanted to travel to Spain could do so under a visa waiver program established in 1963. ${ }^{38}$ And even those that overstayed did not have to bear the high psychological and economic costs associated to being undocumented migrants in the US. In a context of strong economic growth, raids and apprehensions within Spain's borders were virtually non-existing. Moreover, the Spanish government implemented repeated Spanish amnesties (2000, 2001 and 2005; see Figure 3). Thus, it is quite likely that the visa waiver policy played a key role in accounting for Spain's larger power of attraction. Bertoli, Fernández-Huertas Moraga, and Ortega (2010) supply a convincing piece of evidence supporting this interpretation. In August 2003, following European Union directions, Spain started requiring visas to Ecuadorians. These authors show that the inflows of Ecuadorians into Spain fell sharply, from almost eight thousand in the average month over the previous year to less than two thousand individuals in all months between September 2003 and September 2006. In fact, in years 2004 and 2005

institution to which contributions relating to the most recent period were paid shall grant the benefit, the amount of which shall be the sum of the partial benefits authorized by each institution to which the claimant has contributed and shall reflect the percentage of the claimant's contributions, period of contribution and age.'

${ }^{37}$ See Bertoli, Fernández-Huertas Moraga, and Ortega (2010) for a back of the envelope estimate of this risk.

${ }^{38}$ For more details see http://www.boe.es/boe/dias/2003/07/04/pdfs/A26025-26025.pdf 
the US became again the main destination for Ecuadorian migrants.

\section{Conclusions}

This paper presents a version of the Roy-Borjas model where individuals are heterogeneous in the unobserved propensity to migrate. Using individual-level data on an interesting recent episode in international migration, we estimate the role of earnings as a determinant of international migration flows while appropriately accounting for self-selection. Importantly, our data contains earnings and a set of individual characteristics for stayers (in Ecuador) and migrants to all relevant destinations (the US and Spain).

Our main finding is that international migration decisions respond to earnings differences, even in a context where most (Ecuadorian) migrants preferred a relatively low-wage destination (Spain) over one with higher wages (the US). However, our estimates show that changes in expected wages at a particular destination have a larger effect on destination choice conditional on migration than on the overall migration rate. In terms of our model, the reason for this pattern is that migrants tend to have above-average propensities to migrate. As a result their choices are more sensitive to changes in earnings at a particular destination than those of the average stayer, characterized by a low propensity to migrate.

This finding has important implications for the empirical literature aiming at the estimation of the determinants of international migration. It implies that models where bilateral migration flows are assumed to be a function of the difference in expected earnings between each pair of locations are misspecified. Our analysis also suggests that factors other than earnings are crucial determinants of international migration flows.

\section{References}

Batista, C. (2008): "Why Labor Doesn't Flow from Poor to Rich Countries? Micro Evidence from the European Integration Experience," University of Oxford, Department of Economics, Economics Series Working Papers, 402.

Bayer, P., N. Keohane, and C. Timmins (2009): "Migration and Hedonic Valuation: The Case of Air Quality," Journal of Environmental Economics and Management, 58(1), $1-14$. 
Bayer, P., S. Khan, and C. Timmins (2008): "Nonparametric Identification and Estimation in a Generalized Roy Model," NBER Working Paper Series, 13949.

Beckerman, P., and H. Cortés-Douglas (2002): "Ecuador under Dollarization: Opportunities and Risks," In Crisis and Dollarization in Ecuador, edited by Beckerman, P. and Solimano, A.

Beine, M., F. Docquier, and C. Özden (2009): "Diasporas," Journal of Development Economics, forthcoming.

Belot, M. V., and T. J. Hatton (2008): "Immigrant Selection in the OECD," The Australian National University Centre for Economic Policy Research Discussion Paper Series, 571.

Bertoli, S. (2010): "Networks, sorting and self-selection of Ecuadorian migrants," Annales d'Économie et de Statistique, forthcoming.

Bertoli, S., J. Fernández-Huertas Moraga, and F. Ortega (2010): "Immigration Policies and the Ecuadorian Exodus," IZA Discussion Paper, 4737.

BorJas, G. J. (1985): "Assimilation, Changes in Cohort Quality, and the Earnings of Immigrants," Journal of Labor Economics, 3(4), 463-89.

BorJas, G. J. (1987): "Self-Selection and the Earnings of Immigrants," American Economic Review, 77(4), 531-553.

Börsch-Supan, A. (1990): "On the compatibility of nested logit models with utility maximization," Journal of Econometrics, 43, 373-388.

Bourguignon, F., M. Fournier, and M. Gurgand (2007): "Selection Bias Correction Based on the Multinomial Logit Model: Monte Carlo Comparisons," Journal of Economic Surveys, 21(1), 174-205.

Chiquiar, D., and G. H. Hanson (2005): "International Migration, Self-Selection, and the Distribution of Wages: Evidence from Mexico and the United States," Journal of Political Economy, 113(2), 239-281. 
Chiswick, B. R. (1978): "The Effect of Americanization on the Earnings of Foreign-born Men," Journal of Political Economy, 86(5), 897-921.

Clark, X., T. J. Hatton, and J. G. Williamson (2007): "Explaining U.S. Immigration, 1971-1998," The Review of Economics and Statistics, 89(2), 359-373.

Clemens, M., C. E. Montenegro, and L. Pritchett (2008): "The Place Premium: Wage Differences for Identical Workers across the US Border," Center for Global Development Working Paper, 148.

DAнL, G. B. (2002): "Mobility and the Return to Education: Testing a Roy Model with Multiple Markets," Econometrica, 70(6), 2367-2420.

DAly, A. J., AND S. ZACHARY (1979): "Improved multiple choice models," In Identifying and measuring the determinants of mode choice, edited by D. Hensher and Q. Dalvi, Teakfield, London, 335-357.

Dubin, J. A., AND D. L. MCFAdDEn (1984): "An econometric analysis of residential electric appliance holdings and consumption," Econometrica, 52, 345-362.

Elliott, J., And V. Gerova (2005): "Translation from US OCC 2000 to ISCO-88," Center for Longitudinal Studies.

FAlaris, E. F. (1987): “A Nested Logit Migration Model with Selectivity," International Economic Review, 28(2), 429-443.

- (1988): "Migration and Wages of Young Men," The Journal of Human Resources, $23(4), 514-534$.

Fernández-Huertas Moraga, J. (2009): "New Evidence on Emigrant Selection," The Review of Economics and Statistics, forthcoming.

GonzÁlez, L., And F. Ortega (2008): "How Do Very Open Economies Absorb Large Immigration Flows? Recent Evidence from Spanish Regions," IZA Discussion Paper, 3311.

Gratton, B. (2007): "Ecuadorians in the United States and Spain: History, Gender and Niche Formation," Journal of Ethnic and Migration Studies, 33(4), 581-599. 
Grogger, J., and G. H. Hanson (2008): "Income Maximization and the Selection and Sorting of International Migrants," NBER Working Paper Series, 13821.

Hamermesh, D. S., and S. G. Donald (2008): "The effect of college curriculum on earnings: An affinity identifier for non-ignorable non-response bias," Journal of Econometrics, 144(2), 479-491.

Hanson, G. H. (2008): "International Migration and Development," Commission on Growth and Development Working Paper, 42.

Hanson, G. H., and C. McIntosh (2008): "The Great Mexican Emigration," The Review of Economics and Statistics, forthcoming.

(2009): "Birth Rates and Border Crossings: The Demographic Push Behind Emigration in the Americas," mimeo.

Heckman, J. J. (1979): "Sample Selection Bias as a Specification Error," Econometrica, $47,153-161$.

Herriges, J. A., and C. L. Kling (1996): "Testing the Consistency of Nested Logit Models with Utility Maximization," Economics Letters, 50, 33-39.

IbÁÑEZ, J. N. (2006): "Consistency of Nested Logit Models with Utility Maximization," European Transport Conference.

IMF (2000): "Ecuador: Selected Issues and Statistical Annex," IMF Staff Country Report, $00 / 125$.

JÁcome, L. I. (2004): "The Late 1990s Financial Crisis in Ecuador: Institutional Weaknesses, Fiscal Rigidities, and Financial Dollarization at Work," IMF Working Paper, $04 / 12$.

Jokisch, B., And J. Pribilsky (2002): "The Panic to Leave: Economic Crisis and the "New Emigration" from Ecuador," International Migration, 40(4), 76-101.

Kennan, J., And J. R. Walker (2009): "The Effect of Expected Income on Individual Migration Decisions," Econometrica, forthcoming. 
Koning, R. H., And G. Ridder (2003): "Discrete choice and stochastic utility maximization," Econometrics Journal, 6, 1-27.

Laeven, L., and F. Valencia (2008): "Systemic Banking Crises: A New Database," IMF Working Paper, 08/224.

LeE, L.-F. (1983): "Generalized Econometric Models with Selectivity," Econometrica, 51, $507-512$.

MacFadden, D. (1978): "Modeling The Choice of Residential Location," In Spatial Interaction Theories and Models, edited by Karlgvist, A. et al.

MAYDA, A. M. (2008): "International migration: A panel data analysis of the determinants of bilateral flows," Journal of Population Economics, forthcoming.

McKenzie, D. J., and H. Rapoport (2009): "Self-selection patterns in Mexico-U.S. migration: The role of migration networks," The Review of Economics and Statistics, forthcoming.

Nakosteen, R. A., and M. A. Zimmer (1980): "Migration and Income: The Question of Self-Selection," Southern Economic Journal, 46(3), 840-851.

Ortega, F., And G. Peri (2009): "The Causes and Effects of International Labor Mobility: Evidence from OECD Countries 1980-2005," NBER Working Paper Series, 14833.

Pedersen, P. J., M. Pytlikova, and N. Smith (2006): "Migration into OeCD countries 1990-2000," In Parson and Smeeding, editors, Immigration and the Transformation of Europe. Cambridge University Press, Cambridge.

Ramírez Gallegos, F., And J. Ramírez (2005): "La Estampida Migratoria Ecuatoriana: Crisis, redes transnacionales y repertorios de acción migratoria," Abya-Yala, Quito.

Roy, A. D. (1951): "Some Thoughts on the Distribution of Earnings," Oxford Economic Papers, 3, 135-146.

SÁnchez, J. (2004): "Ensayo sobre la economía de la emigración en Ecuador," Ecuador Debate, 63, 47-62. 
SjaAstad, L. A. (1962): "The Costs and Returns of Human Migration," Journal of Political Economy, 70(1), 80-93.

World BANK (2008): "World Development Indicators," Washington. 


\section{Tables and Figures}

\section{Tables}

Table 1: Ecuadorian emigration flows between 1999 and 2005

\begin{tabular}{||l|cc|c||}
\hline \multicolumn{3}{|c|}{ Ecuadorian migrants born in 1949-1982 } \\
\hline & US & Spain & Spain/US \\
\hline Males & 44,410 & 124,586 & 2.8 \\
& $(3,035)$ & $(7,455)$ & $(0.3)$ \\
\hline Non-college & 37,927 & 115,069 & 3.0 \\
& $(2,895)$ & $(7,312)$ & $(0.3)$ \\
College & 6,183 & 9,517 & 1.5 \\
& $(1,030)$ & $(1,790)$ & $(0.4)$ \\
& & & \\
\hline Females & 37,914 & 121,352 & 3.2 \\
& $(2,605)$ & $(6,558)$ & $(0.3)$ \\
\hline Non-college & 29,705 & 102,935 & 3.5 \\
& $(2,342)$ & $(6,131)$ & $(0.4)$ \\
College & 8,209 & 18,417 & 2.2 \\
& $(1,243)$ & $(2,699)$ & $(0.5)$ \\
& & & \\
\hline Both genders & & & \\
Non-college & 67,632 & 218,004 & 3.2 \\
& $(3,571)$ & $(8,909)$ & $(0.2)$ \\
College & 14,392 & 27,934 & 1.9 \\
& $(1,599)$ & $(3,212)$ & $(0.3)$ \\
\hline \multirow{3}{*}{ Total } & & & \\
& $(3,788)$ & $(9,148)$ & $(0.2)$ \\
\hline \hline
\end{tabular}

Source: authors' elaboration on ACS 2007 and ENI 2007. Standard errors in parentheses 
Table 2: Individual characteristics by location

Sample: Ecuadorians born in 1949-1982.

\begin{tabular}{|c|c|c|c|c|c|c|}
\hline \multirow[t]{2}{*}{ Ecuadorians in: } & \multicolumn{2}{|c|}{ Ecuador } & \multicolumn{2}{|c|}{ US } & \multicolumn{2}{|c|}{ Spain } \\
\hline & mean & std.dev. & Mean & std.dev. & mean & std.dev \\
\hline Female & 0.52 & 0.5 & 0.46 & 0.5 & 0.49 & 0.5 \\
\hline \multicolumn{7}{|l|}{ Males } \\
\hline Age at migration & 37.99 & 9.74 & 28.78 & 8.42 & 28.66 & 7.91 \\
\hline Years since migration & - & - & 5.73 & 1.99 & 6.25 & 1.38 \\
\hline Share college graduates & 0.14 & 0.35 & 0.14 & 0.35 & 0.08 & 0.27 \\
\hline Labor income, 2005 USD & 3,565 & 5,471 & 26,896 & 20,344 & 15,979 & 4,214 \\
\hline \multicolumn{7}{|l|}{ Females } \\
\hline Age at migration & 37.97 & 9.49 & 30.22 & 8.54 & 28.91 & 7.54 \\
\hline Years since migration & & & 5.68 & 1.84 & 6.07 & 1.43 \\
\hline Share college graduates & 0.13 & 0.34 & 0.22 & 0.41 & 0.15 & 0.36 \\
\hline Labor income, 2005 USD & 1,509 & 3,147 & 18,189 & 12,718 & 10,767 & 3,317 \\
\hline Obs. & \multicolumn{2}{|c|}{28,122} & \multicolumn{2}{|c|}{509} & \multicolumn{2}{|c|}{915} \\
\hline
\end{tabular}

Source: authors' elaboration on ENEMDU 2005 (Ecuador), ACS 2007 (US) and ENI 2007 (Spain). 
Table 3: $\quad$ Median earnings and employment rates by location

Sample: Ecuadorians born in 1949-1982

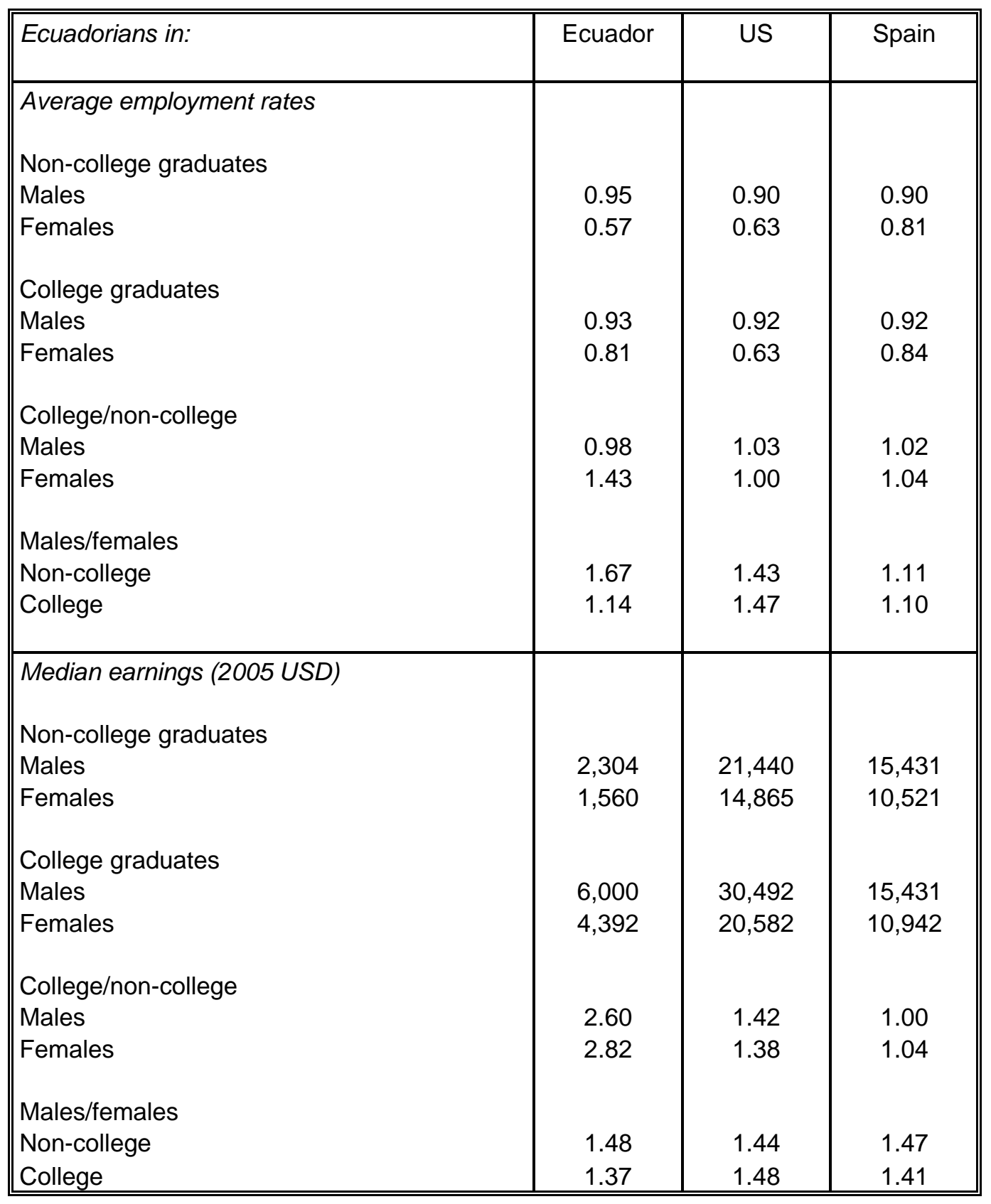

Source: authors' elaboration on ENEMDU 2005 (Ecuador), ACS 2007 (US) and ENI 2007 (Spain). 
Table 4: $\quad$ Tax-adjusted log earnings regressions

Sample: Ecuadorians born in 1949-1982.

Dependent variable: log annual earnings in 2005 USD, net of income taxes.

\begin{tabular}{|c|c|c|c|c|c|c|}
\hline $\begin{array}{l}\text { Country } \\
\text { Spec. }\end{array}$ & $\begin{array}{c}\text { Ecuador } \\
\text { Mincer }\end{array}$ & $\begin{array}{c}\text { Ecuador } \\
\text { Dahl }\end{array}$ & $\begin{array}{c}\text { US } \\
\text { Mincer }\end{array}$ & $\begin{array}{l}\text { US } \\
\text { Dahl }\end{array}$ & $\begin{array}{l}\text { Spain } \\
\text { Mincer }\end{array}$ & $\begin{array}{l}\text { Spain } \\
\text { Dahl }\end{array}$ \\
\hline College graduate & $\begin{array}{c}0.351 \\
{[0.028]^{\star \star \star}}\end{array}$ & $\begin{array}{c}0.308 \\
{[0.030]^{\star \star \star}}\end{array}$ & $\begin{array}{c}0.081 \\
{[0.088]}\end{array}$ & $\begin{array}{c}0.220 \\
{[4.456]}\end{array}$ & $\begin{array}{l}-0.009 \\
{[0.025]}\end{array}$ & $\begin{array}{l}-0.070 \\
{[0.558]}\end{array}$ \\
\hline Female & $\begin{array}{c}-0.354 \\
{[0.015]^{\star \star *}}\end{array}$ & $\begin{array}{c}-0.256 \\
{[0.034]^{\star \star \star}}\end{array}$ & $\begin{array}{c}-0.257 \\
{[0.069]^{\star \star *}}\end{array}$ & $\begin{array}{c}0.133 \\
{[33.832]}\end{array}$ & $\begin{array}{c}-0.274 \\
{[0.028]^{\star \star *}}\end{array}$ & $\begin{array}{l}-0.002 \\
{[5.947]}\end{array}$ \\
\hline Age & $\begin{array}{c}0.013 \\
{[0.003]^{\star \star \star}}\end{array}$ & $\begin{array}{c}0.011 \\
{[0.003]^{\star \star \star}}\end{array}$ & $\begin{array}{c}0.005 \\
{[0.014]}\end{array}$ & $\begin{array}{c}0.004 \\
{[0.015]}\end{array}$ & $\begin{array}{c}0.003 \\
{[0.005]}\end{array}$ & $\begin{array}{c}0.003 \\
{[0.005]}\end{array}$ \\
\hline Age squared & $\begin{array}{c}0.000 \\
{[0.000]^{\star \star \star}}\end{array}$ & $\begin{array}{c}0.000 \\
{[0.000]^{\star \star \star}}\end{array}$ & $\begin{array}{c}0.000 \\
{[0.000]}\end{array}$ & $\begin{array}{c}0.000 \\
{[0.000]}\end{array}$ & $\begin{array}{c}0.000 \\
{[0.000]}\end{array}$ & $\begin{array}{c}0.000 \\
{[0.000]}\end{array}$ \\
\hline Married & $\begin{array}{c}0.126 \\
{[0.014]^{\star \star \star}}\end{array}$ & $\begin{array}{c}0.144 \\
{[0.015]^{\star \star \star}}\end{array}$ & $\begin{array}{c}0.023 \\
{[0.065]}\end{array}$ & $\begin{array}{c}0.036 \\
{[0.072]}\end{array}$ & $\begin{array}{l}-0.034 \\
{[0.021]}\end{array}$ & $\begin{array}{l}-0.031 \\
{[0.023]}\end{array}$ \\
\hline Managers & $\begin{array}{c}1.089 \\
{[0.036]^{\star \star \star}}\end{array}$ & $\begin{array}{c}1.089 \\
{[0.037]^{\star \star \star}}\end{array}$ & $\begin{array}{c}0.358 \\
{[0.183]^{\star}}\end{array}$ & $\begin{array}{c}0.398 \\
{[0.207]^{\star \star}}\end{array}$ & $\begin{array}{c}-0.180 \\
{[0.030]^{\star \star \star}}\end{array}$ & $\begin{array}{l}-0.194 \\
{[0.1481}\end{array}$ \\
\hline Professionals & $\begin{array}{c}0.841 \\
{[0.035]^{\star \star \star}}\end{array}$ & $\begin{array}{c}0.837 \\
{[0.035]^{\star \star \star}}\end{array}$ & $\begin{array}{c}0.539 \\
{[0.278]^{*}}\end{array}$ & $\begin{array}{c}0.571 \\
{[0.279]^{\star \star}}\end{array}$ & $\begin{array}{c}0.026 \\
{[0.149]}\end{array}$ & $\begin{array}{c}0.037 \\
{[0.176]}\end{array}$ \\
\hline Technicians & $\begin{array}{c}0.794 \\
{[0.031]^{\star \star \star}}\end{array}$ & $\begin{array}{c}0.792 \\
{[0.032]^{\star \star \star}}\end{array}$ & $\begin{array}{c}0.117 \\
{[0.188]}\end{array}$ & $\begin{array}{c}0.111 \\
{[0.202]}\end{array}$ & $\begin{array}{l}-0.094 \\
{[0.072]}\end{array}$ & $\begin{array}{c}-0.059 \\
{[0.080]}\end{array}$ \\
\hline Clerical support & $\begin{array}{c}0.785 \\
{[0.033]^{\star \star \star}}\end{array}$ & $\begin{array}{c}0.786 \\
{[0.034]^{\star \star \star}}\end{array}$ & $\begin{array}{c}0.196 \\
{[0.123]}\end{array}$ & $\begin{array}{c}0.210 \\
{[0.129]^{*}}\end{array}$ & $\begin{array}{c}0.084 \\
{[0.054]}\end{array}$ & $\begin{array}{c}0.082 \\
{[0.058]}\end{array}$ \\
\hline Service and sales & $\begin{array}{c}0.398 \\
{[0.021]^{\star \star \star}}\end{array}$ & $\begin{array}{c}0.401 \\
{[0.021]^{\star \star \star}}\end{array}$ & $\begin{array}{l}-0.011 \\
{[0.088]}\end{array}$ & $\begin{array}{l}-0.006 \\
{[0.099]}\end{array}$ & $\begin{array}{c}0.043 \\
{[0.035]}\end{array}$ & $\begin{array}{c}0.039 \\
{[0.035]}\end{array}$ \\
\hline Skilled agriculture & $\begin{array}{c}-0.263 \\
{[0.021]^{\star \star \star}}\end{array}$ & $\begin{array}{c}-0.264 \\
{[0.021]^{\star \star \star}}\end{array}$ & $\begin{array}{l}-0.308 \\
{[0.231]}\end{array}$ & $\begin{array}{l}-0.315 \\
{[0.281]}\end{array}$ & $\begin{array}{l}-0.004 \\
{[0.080]}\end{array}$ & $\begin{array}{c}0.009 \\
{[0.078]}\end{array}$ \\
\hline Craft, rel. trade & $\begin{array}{c}0.260 \\
{[0.022]^{\star \star \star}}\end{array}$ & $\begin{array}{c}0.258 \\
{[0.021]^{\star \star \star}}\end{array}$ & $\begin{array}{c}0.249 \\
{[0.088]^{\star \star \star}}\end{array}$ & $\begin{array}{c}0.255 \\
{[0.094]^{\star \star \star}}\end{array}$ & $\begin{array}{c}0.084 \\
{[0.028]^{\star \star \star}}\end{array}$ & $\begin{array}{c}0.083 \\
{[0.028]^{\star \star \star}}\end{array}$ \\
\hline $\begin{array}{l}\text { Plant, mach. oper. } \\
\text { Constant }\end{array}$ & $\begin{array}{c}0.523 \\
{[0.025]^{\star \star \star}} \\
7.282 \\
{[0.022]^{\star \star \star}}\end{array}$ & $\begin{array}{c}0.517 \\
{[0.025]^{\star \star \star}} \\
6.856 \\
{[0.160]^{\star \star \star}}\end{array}$ & $\begin{array}{c}0.238 \\
{[0.091]^{\star \star \star}} \\
9.738 \\
{[0.123]^{\star \star \star}}\end{array}$ & $\begin{array}{c}0.223 \\
{[0.097]^{\star \star \star}} \\
13.639 \\
{[164.603]}\end{array}$ & $\begin{array}{c}0.096 \\
{[0.031]^{\star \star \star}} \\
9.391 \\
{[0.047]^{\star \star \star}}\end{array}$ & $\begin{array}{c}0.105 \\
{[0.035]^{\star \star \star}} \\
9.881 \\
{[30.088]^{\star}}\end{array}$ \\
\hline $\begin{array}{l}\text { R2 } \\
\text { Observations } \\
\text { F test Dahl pvalue }\end{array}$ & $\begin{array}{c}0.32 \\
18423 \\
\text { n.a. }\end{array}$ & $\begin{array}{c}0.32 \\
18423 \\
0.00\end{array}$ & $\begin{array}{l}0.16 \\
320 \\
\text { n.a. }\end{array}$ & $\begin{array}{l}0.17 \\
320 \\
0.72\end{array}$ & $\begin{array}{l}0.37 \\
716 \\
\text { n.a. }\end{array}$ & $\begin{array}{l}0.38 \\
716 \\
0.20\end{array}$ \\
\hline
\end{tabular}

Note: Standard errors in brackets. Bootstrapped standard errors for the Dahl procedure: 1044 replications selecting the full sample by country with replacement. Dahl models include secondorder polynomial in cell probabilities (not shown). Coding of occupations is ISCO-1 digit, omitted category is elementary occupations.

Source: authors' elaboration on ENEMDU 2005 (Ecuador), ACS 2007 (US) and ENI 2007 (Spain). 
Table 5: Location choice estimates.

Sample: individuals born in 1949-1982.

\begin{tabular}{|c|c|c|c|c|c|}
\hline $\begin{array}{l}\text { Specification } \\
\text { Tax-adjusted earnings } \\
\text { Prediction earnings }\end{array}$ & $\begin{array}{l}{[1]} \\
\text { Main } \\
\text { yes } \\
\text { Dahl }\end{array}$ & $\begin{array}{l}{[2]} \\
\text { No tax } \\
\text { no } \\
\text { Dahl }\end{array}$ & $\begin{array}{l}\text { [3] } \\
\text { Mincer } \\
\text { yes } \\
\text { Mincer }\end{array}$ & $\begin{array}{l}{[4]} \\
\text { Linear } \\
\text { yes } \\
\text { Dahl }\end{array}$ & $\begin{array}{l}{[5]} \\
\text { Logit } \\
\text { yes } \\
\text { Dahl }\end{array}$ \\
\hline $\begin{array}{l}\text { Log earnings } \\
\text { Earnings }\end{array}$ & $\begin{array}{c}0.623 \\
{[0.263]^{\star \star \star}}\end{array}$ & $\begin{array}{c}0.659 \\
{[0.124]^{\star \star \star}}\end{array}$ & $\begin{array}{c}0.592 \\
{[0.121]^{\star \star *}}\end{array}$ & $\begin{array}{c}0.496 \\
{[0.054]^{\star \star \star}}\end{array}$ & $\begin{array}{c}0.752 \\
{[0.187]^{\star \star *}}\end{array}$ \\
\hline United States & & & & & \\
\hline College & $\begin{array}{c}0.093 \\
{[1.428]}\end{array}$ & $\begin{array}{c}0.113 \\
{[0.146]}\end{array}$ & $\begin{array}{c}0.065 \\
{[0.147]}\end{array}$ & $\begin{array}{l}-2.883 \\
{[8.066]}\end{array}$ & $\begin{array}{c}0.368 \\
{[0.183]^{\star}}\end{array}$ \\
\hline Female & $\begin{array}{c}-0.171 \\
{[2.205]^{\star}}\end{array}$ & $\begin{array}{c}-0.161 \\
{[0.076]^{\star \star}}\end{array}$ & $\begin{array}{c}-0.176 \\
{[0.076]^{\star *}}\end{array}$ & $\begin{array}{l}-2.259 \\
{[5.075]}\end{array}$ & $\begin{array}{c}-0.282 \\
{[0.128]^{\star \star}}\end{array}$ \\
\hline Spain & & & & & \\
\hline College & $\begin{array}{c}0.074 \\
{[0.564]}\end{array}$ & $\begin{array}{c}0.098 \\
{[0.159]}\end{array}$ & $\begin{array}{c}0.05 \\
{[0.156]}\end{array}$ & $\begin{array}{c}0.945 \\
{[2.218]}\end{array}$ & $\begin{array}{c}0.109 \\
{[0.225]}\end{array}$ \\
\hline Female & $\begin{array}{l}-0.165 \\
{[0.781]}\end{array}$ & $\begin{array}{c}-0.138 \\
{[0.078]^{\star}}\end{array}$ & $\begin{array}{c}-0.164 \\
{[0.079]^{\star \star}}\end{array}$ & $\begin{array}{c}2.436 \\
{[1.415]^{*}}\end{array}$ & $\begin{array}{c}-0.152 \\
{[0.095]}\end{array}$ \\
\hline Number cases & 29546 & 29546 & 29546 & 29546 & 29546 \\
\hline Dissimilarity coefficient & 0.253 & 0.295 & 0.247 & 59.783 & 1 \\
\hline $\begin{array}{l}\text { S.e. } \\
\text { Share in }(0,1]\end{array}$ & $\begin{array}{c}{[20.912]} \\
0.76\end{array}$ & [0.101] & [0.091] & [141.18/] & \\
\hline US-Spain correlation & 0.936 & 0.913 & 0.939 & n.a. & 0 \\
\hline Log-likelihood & -1262962.4 & -1262466.2 & -1264052.6 & -1236623.4 & -1264483.6 \\
\hline
\end{tabular}

Note: Standard errors in brackets. Bootstrapped standard errors for columns [1] and [5]: 1044 replications selecting the full sample by country with replacement. Model includes controls for age, age squared, marital status, household size, and a country-specific constant. Normalization coefficients that do not vary by destination: equal to zero for Ecuador. The implied correlation coefficient for the linear model (column 4) is not well defined (outside unit interval).

Legend: ${ }^{*} \mathrm{p}<.1 ;{ }^{* *} \mathrm{p}<.05 ;{ }^{* * *} \mathrm{p}<.01$.

Share in $(0,1]$ refers to the share of replications with dissimilarity parameter in unit interval. 
Sources: authors' elaboration on ENEMDU 2005, ACS 2007 and ENI 2007.

Table 6: Average relative migration costs in time-equivalent units

\begin{tabular}{||l|c|c|c||}
\hline Group & US & Spain & US/Spain \\
Male, non-college grad. & 8.5 & 6.5 & 1.3 \\
& {$[0.6]$} & {$[0.2]$} & {$[0.1]$} \\
Male, college grad. & 5.4 & 2.7 & 2.0 \\
& {$[1.0]$} & {$[0.2]$} & {$[0.4]$} \\
Female, non-college grad. & 9.5 & 7.2 & 1.3 \\
& {$[0.9]$} & {$[0.2]$} & {$[0.1]$} \\
Female, college grad. & 5.4 & 3.1 & 1.7 \\
& {$[0.8]$} & {$[0.2]$} & {$[0.3]$} \\
\hline
\end{tabular}

Note: migration costs, recovered on the basis of specification 1 in Table 5, are defined as a ratio to Ecuadorian predicted income. Bootstrapped standard errors in brackets. 
Figures

Figure 1: Macroeconomic Conditions in Ecuador (1995-2005)

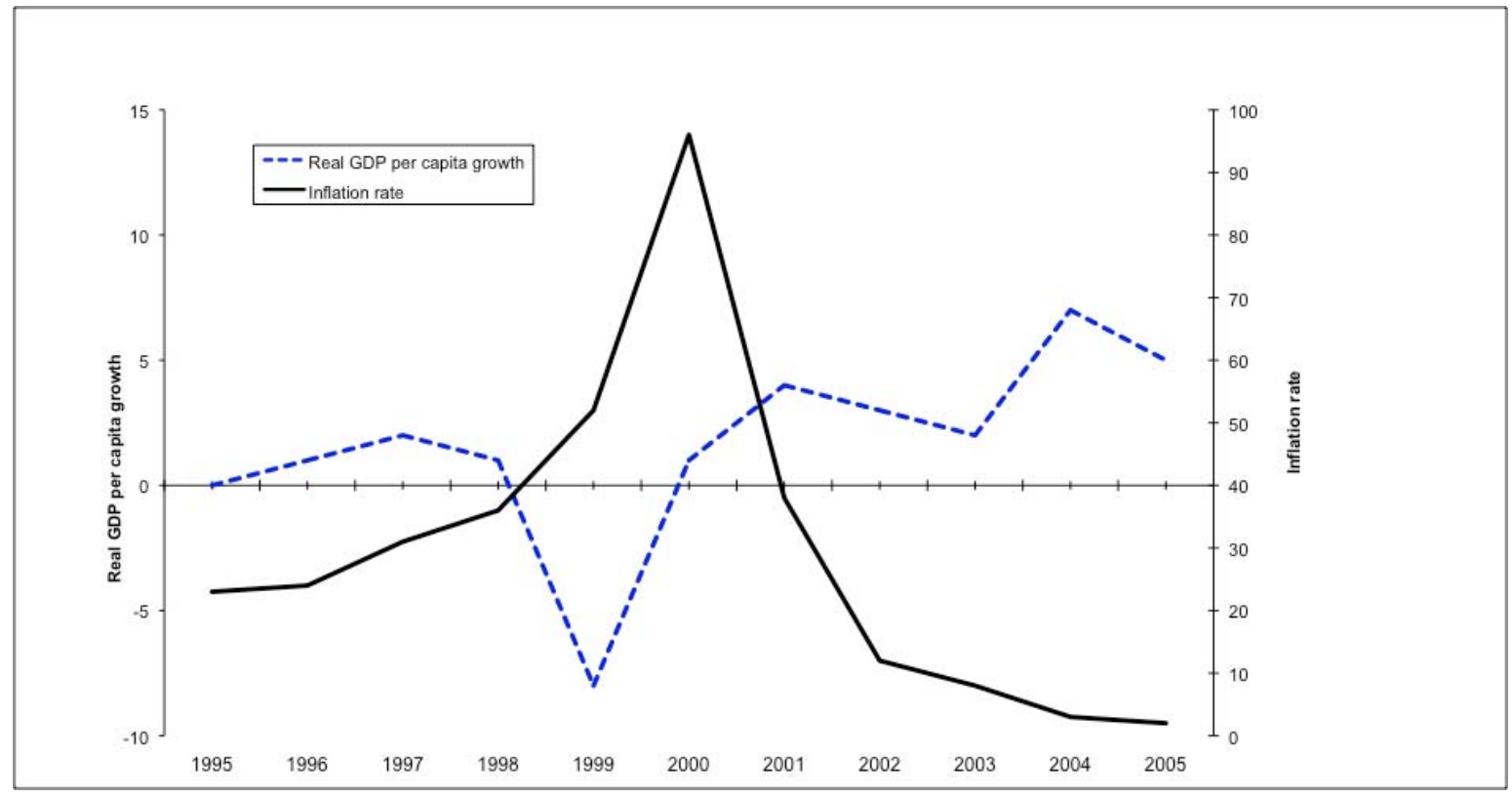

Source: World Development Indicators 2008. 
Figure 2: Arrivals of Ecuadorians in the US according to the ACS 2007

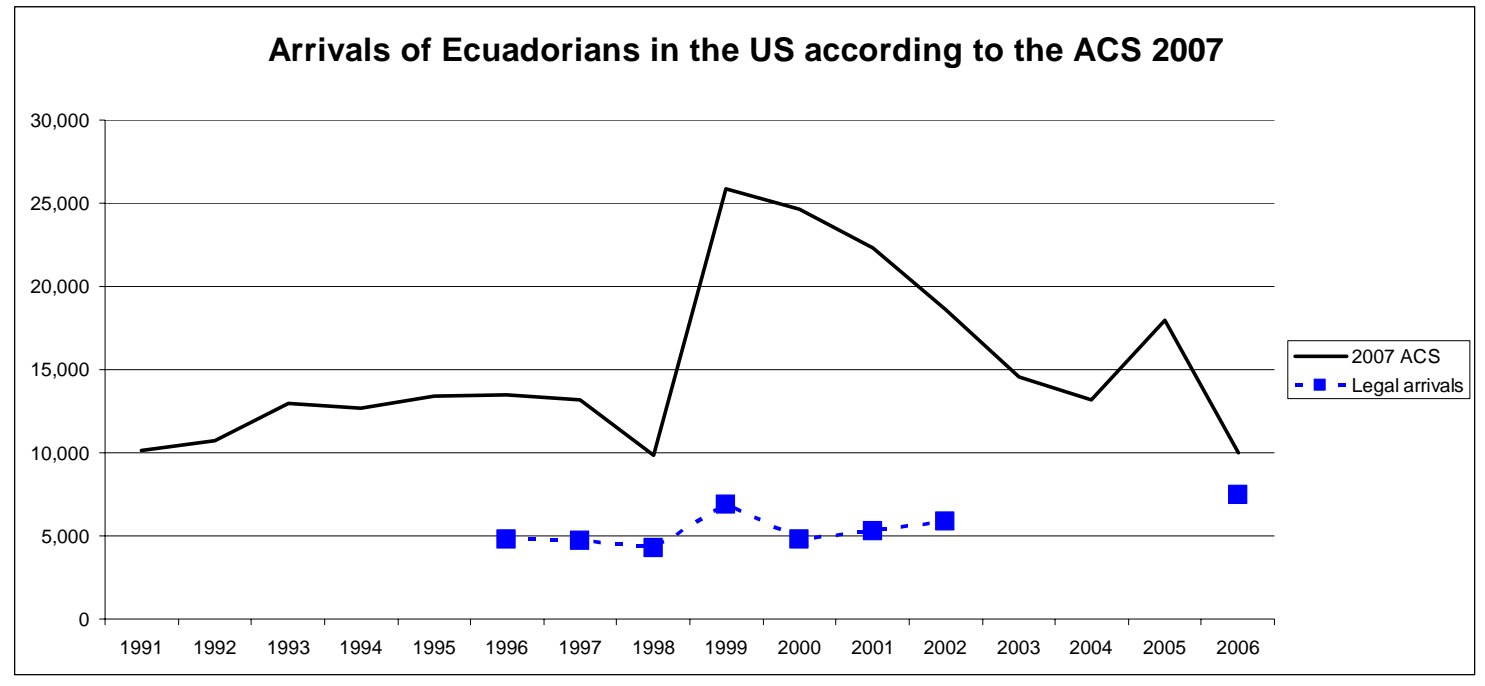

Sources: authors' elaboration on ACS 2007 and INS Immigration Yearbook.

Figure 3: Arrivals of Ecuadorians in Spain according to the ENI 2007

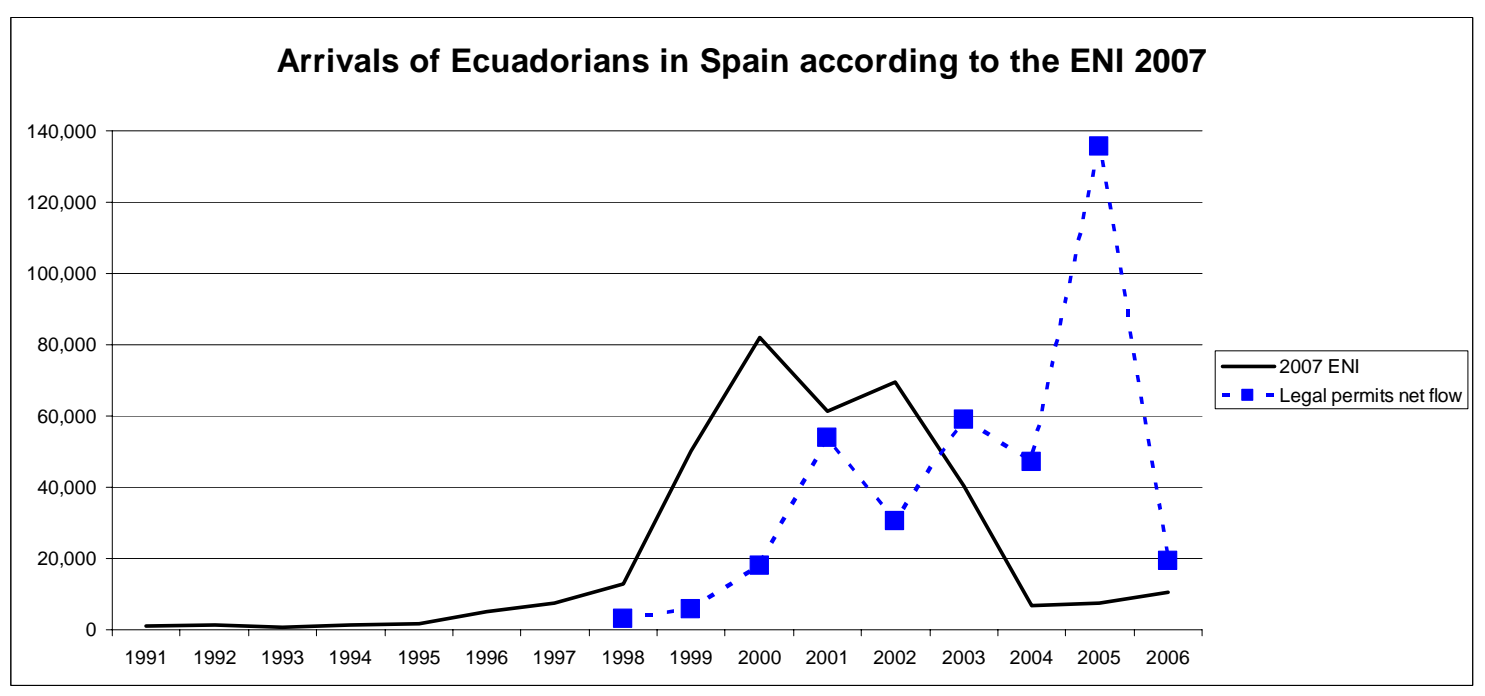

Source: authors' elaboration on ENI 2007 and Spanish Ministry of Work and Immigration Yearbook. 
Figure 4. Income tax schedules in Ecuador, the US and Spain.

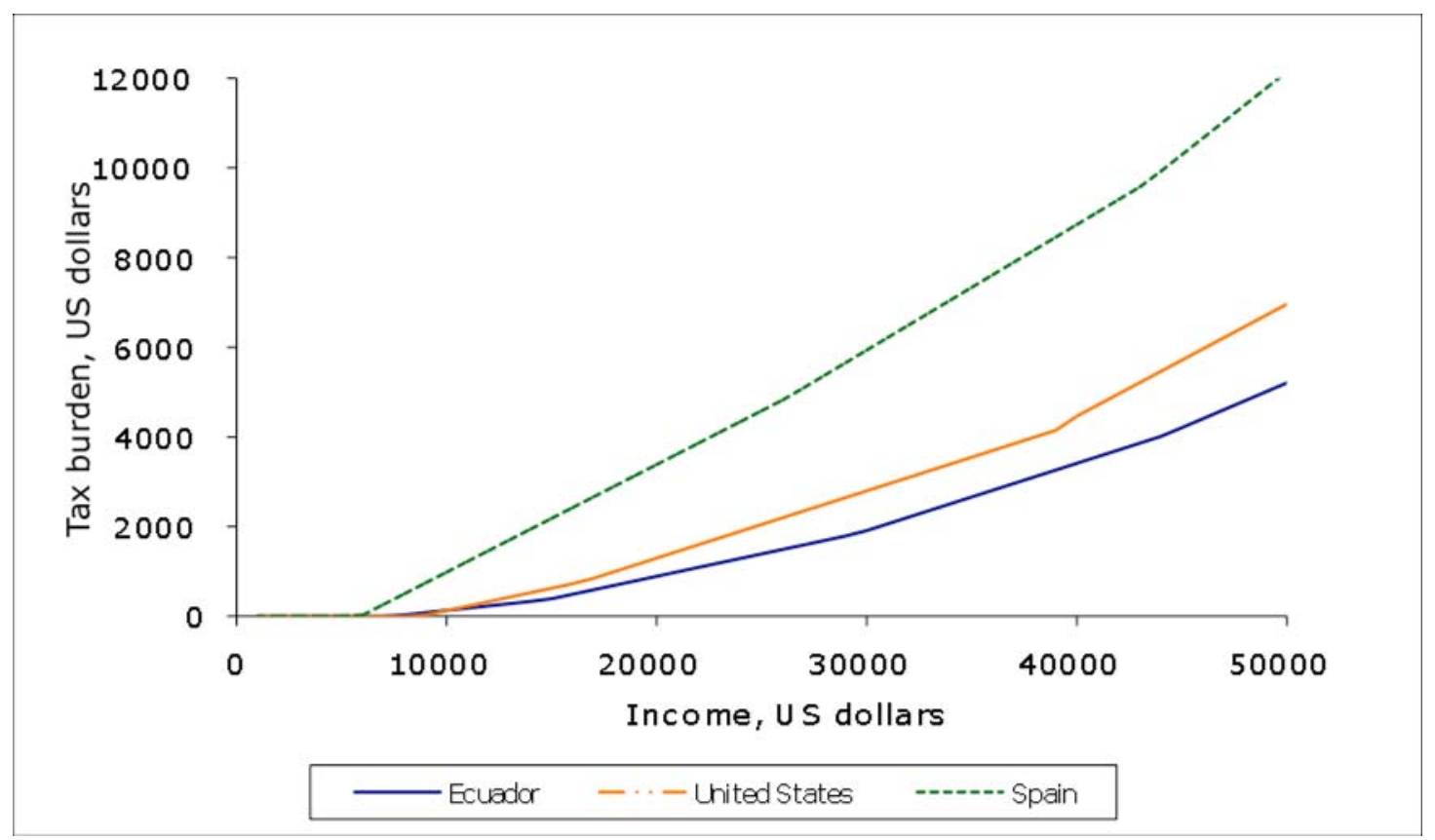

Source: authors' elaboration from the OECD Tax Database and Servicio de Rentas Internas in Ecuador 